\title{
Ozone database in support of CMIP5 simulations: results and corresponding radiative forcing
}

\author{
I. Cionni ${ }^{1}$, V. Eyring ${ }^{1}$, J. F. Lamarque ${ }^{2}$, W. J. Randel $^{2}$, D. S. Stevenson ${ }^{3}$, F. Wu ${ }^{2}$, G. E. Bodeker ${ }^{4,5}$, T. G. Shepherd ${ }^{6}$, \\ D. T. Shindell ${ }^{7}$, and D. W. Waugh ${ }^{8}$ \\ ${ }^{1}$ Deutsches Zentrum für Luft- und Raumfahrt, Institut für Physik der Atmosphäre, Oberpfaffenhofen, Germany \\ ${ }^{2}$ National Center for Atmospheric Research, Boulder, CO, USA \\ ${ }^{3}$ School of GeoSciences, University of Edinburgh, Edinburgh, UK \\ ${ }^{4}$ Bodeker Scientific, Alexandra, New Zealand \\ ${ }^{5}$ National Institute of Water and Atmospheric Research, Lauder, New Zealand \\ ${ }^{6}$ University of Toronto, Department of Physics, Toronto, Canada \\ ${ }^{7}$ NASA Goddard Institute for Space Studies, New York, New York, USA \\ ${ }^{8}$ Johns Hopkins University, Department of Earth and Planetary Sciences, Baltimore, Maryland, USA
}

Received: 8 February 2011 - Published in Atmos. Chem. Phys. Discuss.: 7 April 2011

Revised: 17 September 2011 - Accepted: 21 September 2011 - Published: 14 November 2011

\begin{abstract}
A continuous tropospheric and stratospheric vertically resolved ozone time series, from 1850 to 2099 , has been generated to be used as forcing in global climate models that do not include interactive chemistry. A multiple linear regression analysis of SAGE I+II satellite observations and polar ozonesonde measurements is used for the stratospheric zonal mean dataset during the well-observed period from 1979 to 2009. In addition to terms describing the mean annual cycle, the regression includes terms representing equivalent effective stratospheric chlorine (EESC) and the 11-yr solar cycle variability. The EESC regression fit coefficients, together with pre-1979 EESC values, are used to extrapolate the stratospheric ozone time series backward to 1850 . While a similar procedure could be used to extrapolate into the future, coupled chemistry climate model (CCM) simulations indicate that future stratospheric ozone abundances are likely to be significantly affected by climate change, and capturing such effects through a regression model approach is not feasible. Therefore, the stratospheric ozone dataset is extended into the future (merged in 2009) with multimodel mean projections from $13 \mathrm{CCMs}$ that performed a simulation until 2099 under the SRES (Special Report on Emission Scenarios) A1B greenhouse gas scenario and the A1 adjusted halogen scenario in the second round of the Chemistry-Climate Model Validation (CCMVal-2) Activity. The stratospheric zonal mean ozone time series is merged
\end{abstract}

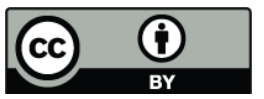

Correspondence to: I. Cionni (irene.cionni@dlr.de) with a three-dimensional tropospheric data set extracted from simulations of the past by two CCMs (CAM3.5 and GISSPUCCINI) and of the future by one CCM (CAM3.5). The future tropospheric ozone time series continues the historical CAM3.5 simulation until 2099 following the four different Representative Concentration Pathways (RCPs). Generally good agreement is found between the historical segment of the ozone database and satellite observations, although it should be noted that total column ozone is overestimated in the southern polar latitudes during spring and tropospheric column ozone is slightly underestimated. Vertical profiles of tropospheric ozone are broadly consistent with ozonesondes and in-situ measurements, with some deviations in regions of biomass burning. The tropospheric ozone radiative forcing (RF) from the 1850 s to the 2000 s is $0.23 \mathrm{~W} \mathrm{~m}^{-2}$, lower than previous results. The lower value is mainly due to (i) a smaller increase in biomass burning emissions; (ii) a larger influence of stratospheric ozone depletion on upper tropospheric ozone at high southern latitudes; and possibly (iii) a larger influence of clouds (which act to reduce the net forcing) compared to previous radiative forcing calculations. Over the same period, decreases in stratospheric ozone, mainly at high latitudes, produce a RF of $-0.08 \mathrm{~W} \mathrm{~m}^{-2}$, which is more negative than the central Intergovernmental Panel on Climate Change (IPCC) Fourth Assessment Report (AR4) value of $-0.05 \mathrm{~W} \mathrm{~m}^{-2}$, but which is within the stated range of -0.15 to $+0.05 \mathrm{~W} \mathrm{~m}^{-2}$. The more negative value is explained by the fact that the regression model simulates significant ozone depletion prior to 1979 , in 
line with the increase in EESC and as confirmed by CCMs, while the AR4 assumed no change in stratospheric RF prior to 1979. A negative RF of similar magnitude persists into the future, although its location shifts from high latitudes to the tropics. This shift is due to increases in polar stratospheric ozone, but decreases in tropical lower stratospheric ozone, related to a strengthening of the Brewer-Dobson circulation, particularly through the latter half of the 21st century. Differences in trends in tropospheric ozone among the four RCPs are mainly driven by different methane concentrations, resulting in a range of tropospheric ozone RFs between 0.4 and $0.1 \mathrm{~W} \mathrm{~m}^{-2}$ by 2100 . The ozone dataset described here has been released for the Coupled Model Intercomparison Project (CMIP5) model simulations in netCDF Climate and Forecast (CF) Metadata Convention at the PCMDI website (http://cmip-pcmdi.llnl.gov/).

\section{Introduction}

The Working Group on Coupled Modelling (WGCM) of the World Climate Research Programme (WCRP) has agreed on a new set of coordinated climate model experiments (Taylor et al., 2009). This set of climate model simulations forms phase five of the Coupled Model Intercomparison Project (CMIP5). The purpose of these experiments is to address outstanding scientific questions that arose as part of the Intergovernmental Panel on Climate Change (IPCC) Fourth Assessment Report (AR4), to improve understanding of climate, and to provide estimates of future climate change. Since not all coupled models participating in CMIP5 have interactive chemistry, there is a need to provide fields of radiatively important gases and aerosols to force these models. To this end, a joint effort of the Chemistry-Climate Model Validation (CCMVal, http://www.pa.op.dlr.de/CCMVal) Activity of WCRP's Stratospheric Processes and their Role in Climate (SPARC) project and the Atmospheric Chemistry and Climate (AC\&C, http://igac.jisao.washington.edu/ACandC. php) initiative was established, to generate an ozone concentration data set as a function of latitude, altitude and time. Prescribing a continuous ozone time series from the past into the future, rather than prescribing a static ozone climatology, ensures that ozone is more realistically represented in the CMIP5 simulations that do not have interactive chemistry. In IPCC AR4, around half of the climate models prescribed a constant ozone climatology (see e.g. Son et al., 2008).

Several studies indicate that a correct representation of stratospheric and tropospheric ozone is crucial for reproducing past trends in climate variables as well as for providing reliable projections of surface climate change and temperature trends. For example, previous work indicates that the tropospheric ozone burden has increased by around $70 \mathrm{Tg}$ $(\sim 30 \%)$ between 1890 and 1990 leading to a global mean $\mathrm{RF}$ of around $0.35 \mathrm{~W} \mathrm{~m}^{-2}\left[+0.25\right.$ to $\left.+0.65 \mathrm{~W} \mathrm{~m}^{-2}\right]$ in 2005
(IPCC, 2007). This has largely resulted from increases in ozone precursor emissions due to anthropogenic activities, but climate processes may also have played a role (Gauss et al., 2006). For example, several studies indicate that under future climate change, tropospheric ozone may reduce due to increased destruction related to higher absolute humidities (Johnson et al., 2001). On the other hand, ozone may increase due to positive climate feedbacks such as an increased influx from the stratosphere (Collins et al., 2003; Shindell et al., 2006; Hegglin and Shepherd, 2009), or higher biogenic VOC emissions (Sanderson et al., 2003; Hauglustaine et al., 2005). The net impact of climate change on tropospheric ozone is uncertain, but it is likely to vary significantly by region, altitude, and season (Stevenson et al., 2006; Isaksen et al., 2009; Jacob and Winner, 2009). In addition to past and expected future changes in tropospheric ozone, stratospheric ozone has been subject to a major perturbation since the late 1970s due to anthropogenic emissions of ozone-depleting substances (ODSs), now controlled under the Montreal Protocol. It is necessary to account for the climate effects of stratospheric ozone depletion and recovery to correctly detect and attribute greenhouse gas (GHG) induced climate change. In particular, the ozone hole has been the primary driver of changes in Southern Hemisphere summertime high-latitude surface climate over the past few decades (Thompson and Solomon, 2002, 2005; Thompson et al., 2005). Due to the projected disappearance of the ozone hole during the 21 st century, a deceleration of the poleward side of the jet (a decrease in the Southern Annular Mode) is simulated by most stratosphere-resolving Chemistry Climate Models (CCMs) (SPARC CCMVal, 2010; Perlwitz et al., 2008; Son et al., 2008). This is opposite to the response found in the mean of the IPCC AR4 models that did not include interactive chemistry and prescribed constant climatological ozone. The future evolution of stratospheric ozone will be affected not only by ODSs but also by climate change. An increase in upper stratospheric ozone is expected from $\mathrm{CO}_{2}$-induced cooling, and a decrease in tropical ozone and an increase in extratropical ozone in the lower stratosphere is expected to follow a strengthening of the Brewer-Dobson circulation (Butchart et al., 2006; SPARC CCMVal, 2010; Eyring et al., 2007; Shepherd, 2008).

This paper describes the AC\&C/SPARC ozone database that has been created in support of CMIP5. The dataset covers the period 1850 to 2100 and can be used as ozone forcing in CMIP5 models that do not include interactive chemistry. The dataset has been released to the climate community in netCDF Climate and Forecast (CF) Metadata Convention at the PCMDI CMIP5 website (http://cmip-pcmdi.llnl.gov/). Section 2 describes the method that has been used to create the ozone database, while Sect. 3 presents the results and a comparison with in situ and ozonesonde observations. Section 4 summarizes the corresponding radiative forcing (RF) and Sect. 5 closes with a summary and discussion. 


\section{Method and data}

\subsection{Historical segment of the ozone database (1850-2009)}

The historical segment of the ozone database covers the period 1850 to 2009 and combines separate stratospheric and tropospheric data sources. An overview of all data sources and their formats is given in Table 1. The most accurate option for reproducing historical time varying radiative forcing from ozone is to create a three dimensional (latitude, longitude, altitude) ozone time series based on observations. However, observations are not available for the entire period and for the whole atmosphere. Therefore, regressionbased data filling or output from CCMs is used to provide a database with full coverage.

Stratospheric observations are taken from Randel and $\mathrm{Wu}$ (2007). They are constructed using a multiple linear regression analysis of Stratospheric Aerosol and Gas Experiment (SAGE) I+II satellite observations combined with polar ozonesonde data from Syowa $\left(69^{\circ} \mathrm{S}\right)$ and Resolute $\left(75^{\circ} \mathrm{N}\right)$ for the period 1979-2005. The interannual changes derived from this data set are then combined with a seasonally varying ozone climatology from Fortuin and Kelder (1998) to provide a monthly global data set. The regression includes terms representing EESC and 11-yr solar cycle variability. Thus, other sources of interannual variability, including volcanic eruptions and the Quasi-Biennial Oscillation (QBO), are removed. The zonal mean stratospheric time series is extended backwards to 1850 based on the regression fits combined with extended proxy time series of EESC and solar variability. The stratospheric and tropospheric data are combined by merging the two data sets across a climatological tropopause derived from NCEP/NCAR reanalyses. A netCDF file of the tropopause climatology can be found in the supplementary information. For each profile, the tropospheric ozone data are used up to the altitude closest (but below) the tropopause, and the stratospheric ozone data are used for higher levels.

Before the 1960s, very few direct observations of tropospheric ozone are available (Marenco et al., 1994 and references therein). Furthermore, unlike in the stratosphere, a multiple linear regression of the temporal evolution on factors such as EESC is not possible to define the tropospheric ozone distribution. Indeed, the distribution of precursor emissions (and their changes with time) is strongly localized and does not allow for simple correlation functions. Tropospheric ozone estimates are therefore derived from CCM simulations. The tropospheric ozone simulations were performed using the Community Atmosphere Model version 3.5 (CAM3.5, Lamarque et al., 2010a) and the NASA GISS model for Physical Understanding of Composition-Climate INteractions and Impacts (GISS-PUCCINI, Shindell et al., 2006). Both models simulate tropospheric and stratospheric chemistry with feedback to the radiation and were driven by historical (1850-2000) emissions described in Lamarque et al. (2010a). Emissions are kept constant from 2000 to 2009 in both historical simulations. In addition, CAM3.5 used sea surface temperatures (SSTs) and sea ice concentrations (SICs) from a previous simulation with the Community Climate System Model Version 3 (CCSM3) while the GISSPUCCINI model used observed SSTs (Hadley Centre dataset of Rayner et al., 2003). The simulation from CAM3.5 was a transient simulation from 1850 to 2005 (after a 10-yr spin-up at 1850) while the GISS-PUCCINI model performed timeslice experiments every $20 \mathrm{yr}$ between 1850 and 1930 and every $10 \mathrm{yr}$ thereafter. Each time-slice experiment was run for eight years with two years spin-up, so that the last six years of each simulation are used to calculate the climatological mean for the corresponding decade. The GISS-PUCCINI results were interpolated to the CAM3.5 vertical grid and an average of both was taken. This average field represents the historical tropospheric ozone field in the ozone database. The decadal climatological means were linearly interpolated to create annual values, which means that the data have decadal smoothing included, even though it is annual (i.e. it does not represent sub-decadal variability).

\subsection{Future segment of the ozone database (2010-2099)}

The future segment of the ozone database covers the period 2010 to 2099 and is merged with the historical time series in 2009.

The three dimensional (latitude, longitude, altitude) future tropospheric ozone time series continues the historical CAM3.5, but not PUCCINI, simulation until 2099 following the four different Representative Concentration Pathways (RCPs). The RCP emissions were generated by Integrated Assessment Models (IAMs) and harmonized with the historical emissions from Lamarque et al. (2010a) in both amplitude and geographical distribution. The four RCP simulations performed with CAM3.5 (Lamarque et al., 2010b) are RCP 8.5 (Riahi et al., 2007), RCP 6.0 (Fujino et al., 2006; Lamarque et al., 2011; Hijioka et al., 2008), RCP 4.5 (Clarke et al., 2007), and RCP 2.6 (van Vuuren et al., 2007). The number after "RCP" indicates the radiative forcing from long-lived greenhouse gases in $\mathrm{W} \mathrm{m}^{-2}$ reached by 2100 in each scenario. Since RCP simulations from a coupled climate model were not available at the time the simulations were started, SSTs and SICs from SRES (Special Report on Emission Scenarios) simulations closest to the RCP GHG scenarios were used (CCSM3 commitment, SRES B1, SRES A1B, and SRES A2 for RCP 2.6, 4.5, 6.0, and 8.5, respectively, where in the commitment simulation concentrations of all atmospheric constituents were held fixed at year 2000 values). The time series for the greenhouse gas concentrations (methane $\left(\mathrm{CH}_{4}\right)$, carbon dioxide $\left(\mathrm{CO}_{2}\right)$, nitrous oxide $\left(\mathrm{N}_{2} \mathrm{O}\right)$ ), as well as for ozone precursor emissions (nitrogen oxides $\left(\mathrm{NO}_{\mathrm{x}}\right)$, carbon monoxide (CO), volatile organic compounds (VOCs)) are shown in Fig. 1 (see original datasets 
Table 1. Summary of data sources used in the AC\&C/SPARC ozone database.

\begin{tabular}{|c|c|c|c|c|c|}
\hline \multicolumn{3}{|c|}{ STRATOSPERE } & \multicolumn{3}{|c|}{ TROPOSPHERE } \\
\hline Period & Format & Data source & Period & Format & Data source \\
\hline 1850-1978 & $\begin{array}{l}\text { Monthly mean time } \\
\text { varying zonal mean } \\
\text { field (altitude, } \\
\text { latitude, time) that } \\
\text { considers solar } \\
\text { variability }\end{array}$ & $\begin{array}{l}\text { The EESC regres- } \\
\text { sion fit coefficients, } \\
\text { together with } \\
\text { pre- } 1979 \text { EESC } \\
\text { values, are used } \\
\text { to extrapolate the } \\
\text { stratospheric ozone } \\
\text { time series back- } \\
\text { ward to cover the } \\
\text { period }\end{array}$ & 1850-2009 & $\begin{array}{l}\text { Monthly mean time } \\
\text { varying 3-D field } \\
\text { (altitude, latitude, } \\
\text { longitude time) }\end{array}$ & $\begin{array}{l}\text { Two-model mean } \\
\text { derived from } \\
\text { CAM3.5 } \\
\text { (Lamarque et al., } \\
\text { 2010a) and GISS- } \\
\text { PUCCINI (Shindell } \\
\text { et al., 2006) } \\
\text { simulations. }\end{array}$ \\
\hline 1979-2009 & $\begin{array}{l}\text { Monthly mean time } \\
\text { varying zonal mean } \\
\text { field (altitude, } \\
\text { latitude, time) that } \\
\text { considers solar } \\
\text { variability }\end{array}$ & $\begin{array}{l}\text { Multiple linear } \\
\text { regression analysis } \\
\text { of SAGE I+II } \\
\text { satellite observa- } \\
\text { tions and polar } \\
\text { ozonesonde } \\
\text { measurements from } \\
\text { Syowa }\left(69^{\circ} \mathrm{S}\right) \text { and } \\
\text { Resolute }\left(75^{\circ} \mathrm{N}\right)\end{array}$ & & & \\
\hline $\begin{array}{l}\text { 2010-2099 } \\
\text { Single scenario: } \\
\text { adjusted A1 } \\
\text { halocarbons } \\
\text { scenario and } \\
\text { SRES A1B GHG } \\
\text { scenario. }\end{array}$ & $\begin{array}{l}\text { Monthly mean time } \\
\text { varying zonal mean } \\
\text { field (altitude, } \\
\text { latitude, time) that } \\
\text { does not considers } \\
\text { solar variability }\end{array}$ & $\begin{array}{l}\text { CCMVal-2 } \\
\text { 13-model, see } \\
\text { Table } 2 \text { and SPARC } \\
\text { CCMVal (2010) }\end{array}$ & $\begin{array}{l}\mathbf{2 0 1 0 - 2 0 9 9} \\
\text { Four scenarios: } \\
\text { RCP } 2.6,4.5 \text {, } \\
6.0 \text {, and } 8.5 \text {. }\end{array}$ & $\begin{array}{l}\text { Monthly mean time } \\
\text { varying 3D field } \\
\text { (altitude, latitude, } \\
\text { longitude time) }\end{array}$ & $\begin{array}{l}\text { CAM3.5 RCP } \\
\text { 2.6, } 4.5,6.0, \text { and } \\
8.5 \text { simulations } \\
\text { (Lamarque et al., } \\
\text { 2010a). }\end{array}$ \\
\hline
\end{tabular}

at http://www.iiasa.ac.at/web-apps/tnt/RcpDb/). While the ozone precursor emissions $\mathrm{NO}_{\mathrm{x}}, \mathrm{CO}$, and VOCs are somewhat different in the four RCPs, large differences among the RCPs exist for the greenhouse gases, including the ozone precursor methane $\left(\mathrm{CH}_{4}\right) . \mathrm{CH}_{4}$ concentrations in the RCP 8.5 scenario increase substantially above today's values ( $\sim 1750 \mathrm{ppb})$ to above $3500 \mathrm{ppb}$ by 2100 , while in RCP 4.5 and RCP $6.0 \mathrm{CH}_{4}$ is similar to today's values in 2100 and decreases to $\sim 1250 \mathrm{ppb}$ in the RCP 2.6 scenario. Since methane is a strong contributor to ozone formation, such large variations in methane concentrations by 2100 will significantly contribute to variations in tropospheric ozone. It is however important to recognize that potentially important simplifications were used for the generation of those concentrations (Meinshausen et al., 2011). These include a simplified representation of the methane self-impact on its lifetime, the climate impact on $\mathrm{OH}$ and, possibly more importantly, the lack of consideration of variable natural emissions of methane, especially wetlands. $\mathrm{CO}_{2}$ concentrations vary from $\sim 935 \mathrm{ppm}$ in the RCP 8.5 scenarios to $420 \mathrm{ppm}$ in the RCP 2.6 scenario in 2100 , while $\mathrm{N}_{2} \mathrm{O}$ ranges from 345 to $435 \mathrm{ppm}$, respectively.
The two-dimensional (latitude, altitude) monthly mean stratospheric ozone projections are taken from the future reference simulations (REF-B2) of 13 CCMs that performed this simulation to 2099 in CCMVal-2 at the time the ozone database was created. These models, which do not have detailed tropospheric chemistry, are listed in Table 2 along with their horizontal resolution and uppermost height/pressure level. They are described in detail in the references cited as well as in Morgenstern et al. (2010) and Chapter 2 of SPARC CCMVal (2010). REF-B2 is the so-called reference simulation and is a transient simulation from 1960 to 2100 . In this simulation the surface time series of halocarbons are based on the adjusted A1 scenario from WMO (2007), which includes the earlier phase out of hydrochlorofluorocarbons (HCFCs) that was agreed to by the Parties to the Montreal Protocol in 2007. The long-lived GHG surface concentrations are taken from the SRES A1B scenario (IPCC, 2001). External natural forcings such as solar variability and volcanic eruptions are not considered, as they cannot be known in advance, and in any case would have little impact on longterm changes in radiative forcing. It should be noted that only one of the CCMs (CMAM) was coupled to an ocean 
Table 2. Stratospherically resolving chemistry-climate models (CCMs) that are included in the multi-model mean stratospheric ozone projections in this database.

\begin{tabular}{|c|c|c|c|c|c|c|}
\hline & $\mathrm{CCM}$ & Group and Location & Horiz. Res. & Upper level & REF-B2 & References \\
\hline 1 & AMTRAC3 & GFDL, USA & $\sim 200 \mathrm{~km}$ & $0.017 \mathrm{hPa}$ & REF-B2 & Austin et al. (2009) \\
\hline 2 & CAM3.5 & NCAR, USA & $1.9^{\circ} \times 2.5^{\circ}$ & $3.5 \mathrm{hPa}$ & REF-B2 & Lamarque et al. (2008) \\
\hline 3 & CCSRNIES & NIES, Tokyo, Japan & $\mathrm{T} 42$ & $0.012 \mathrm{hPa}$ & REF-B2 & Akiyoshi et al. (2009) \\
\hline 4 & CMAM & $\begin{array}{l}\text { Environment Canada, University } \\
\text { of Toronto, York Univ., Canada }\end{array}$ & T31 & $0.00081 \mathrm{hPa}$ & $3 \times \mathrm{REF}-\mathrm{B} 2$ & $\begin{array}{l}\text { Scinocca et al. (2008); Fomichev } \\
\text { et al. (2007); de Grandpré et al., (2000) }\end{array}$ \\
\hline 5 & CNRM-ACM & Meteo-France; France & T63 & $0.07 \mathrm{hPa}$ & REF-B2 & Déqué (2007); Teyssèdre et al. (2007) \\
\hline 6 & GEOSCCM & NASA/GSFC, USA & $2^{\circ} \times 2.5^{\circ}$ & $0.015 \mathrm{hPa}$ & REF-B2 & Pawson et al. (2008) \\
\hline 7 & LMDZrepro & IPSL, France & $2.5^{\circ} \times 3.75^{\circ}$ & $0.07 \mathrm{hPa}$ & REF-B2 & Jourdain et al. (2008) \\
\hline 8 & MRI & MRI, Japan & $\mathrm{T} 42$ & $0.01 \mathrm{hPa}$ & $2 \times$ REF-B 2 & Shibata and Deushi $(2008 b, a)$ \\
\hline 9 & SOCOL & $\begin{array}{l}\text { PMOD/WRC and ETHZ, } \\
\text { Switzerland }\end{array}$ & $\mathrm{T} 30$ & $0.01 \mathrm{hPa}$ & $3 \times$ REF-B2 & $\begin{array}{l}\text { Egorova et al., (2005); } \\
\text { Schraner et al. (2008) }\end{array}$ \\
\hline 10 & ULAQ & University of L'Aquila, Italy & $\mathrm{R} 6 / 11.5^{\circ} \times 22.5^{\circ}$ & $0.04 \mathrm{hPa}$ & $3 \times \mathrm{REF}-\mathrm{B} 2$ & $\begin{array}{l}\text { Eyring et al. (2006); Eyring et } \\
\text { al. (2007); Pitari et al. (2002) }\end{array}$ \\
\hline 11 & UMSLIMCAT & University of Leeds, UK & $2.5^{\circ} \times 3.75^{\circ}$ & $0.01 \mathrm{hPa}$ & REF-B2 & $\begin{array}{l}\text { Tian and Chipperfield (2005); } \\
\text { Tian et al. (2006) }\end{array}$ \\
\hline 12 & UMUKCA-UCAM & University of Cambridge, UK & $2.5^{\circ} \times 3.75^{\circ}$ & $84 \mathrm{~km}$ & REF-B2 & $\begin{array}{l}\text { Morgenstern et al. (2008); } \\
\text { Morgenstern et al. (2009) }\end{array}$ \\
\hline 13 & WACCM & NCAR, USA & $1.9^{\circ} \times 2.5^{\circ}$ & $5.9603 \times 10^{-6} \mathrm{hPa}$ & $3 \times$ REF-B2 & Garcia et al. (2007) \\
\hline
\end{tabular}
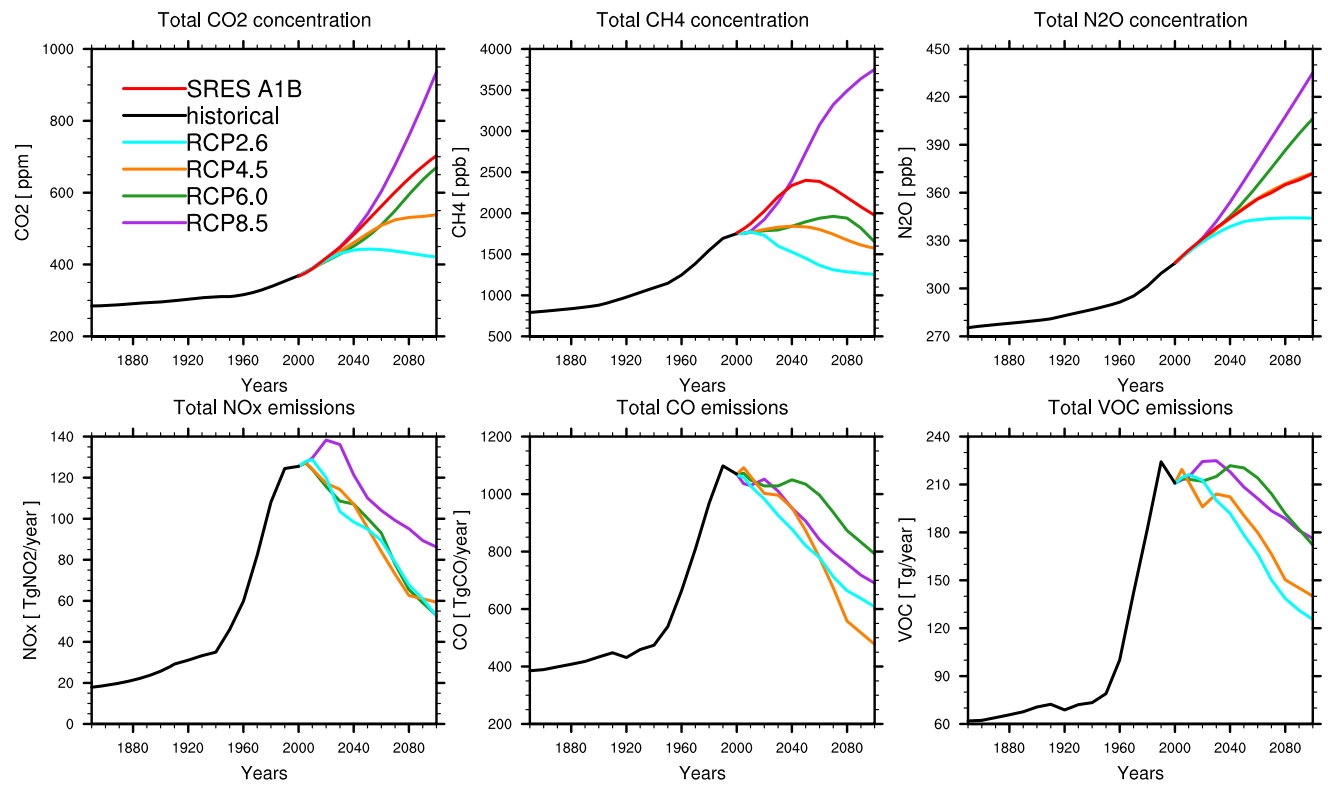

Fig. 1. Time series of different greenhouse gas concentrations for (a) $\mathrm{CO}_{2}$, (b) $\mathrm{CH}_{4}$ and (c) $\mathrm{N}_{2} \mathrm{O}$ as well as emission scenarios for (d) $\mathrm{NO}_{\mathrm{x}}$, (e) CO and (f) VOC in the historical period (1850 to 2000) and for the four RCPs (2000 to 2100). Additionally, the GHG scenarios are shown for the SRES A1B scenario.

in CCMVal-2, whereas in all other CCMs SSTs and seaice concentrations are prescribed. The CCMs have been extensively evaluated as part of the SPARC CCMVal Report (SPARC CCMVal, 2010). The setup of the REF-B2 simulations is further described in Eyring (2008) and Chapter 2 of SPARC CCMVal (2010).

To merge the future tropospheric data with the stratospheric data, first a linear re-gridding of the ozone data at the same levels, latitudes and longitudes of the historical database (37 latitudes and 72 longitudes) is performed. A linear interpolation is also used to obtain a monthly mean time series that spans the period from 2010 to 2099 . Finally, as in the historical part, the future stratospheric and tropospheric data are spliced together by merging the two data sets across the climatological tropopause derived from NCEP/NCAR reanalyses (see also Sect. 2.2), to produce a smooth final data set from 1850 to 2100 . 

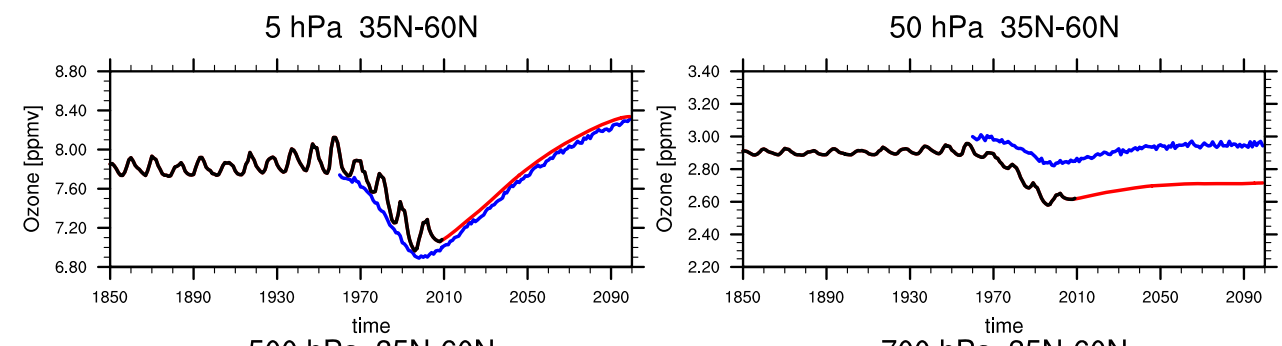

$500 \mathrm{hPa} 35 \mathrm{~N}-60 \mathrm{~N}$

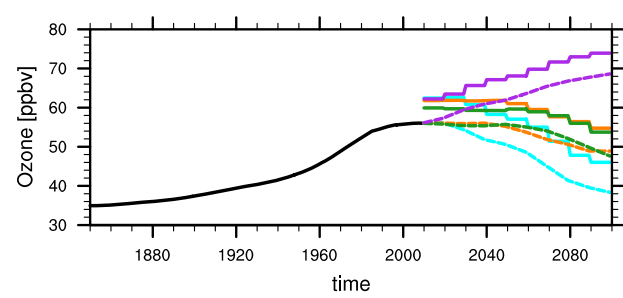

$700 \mathrm{hPa} 35 \mathrm{~N}-60 \mathrm{~N}$
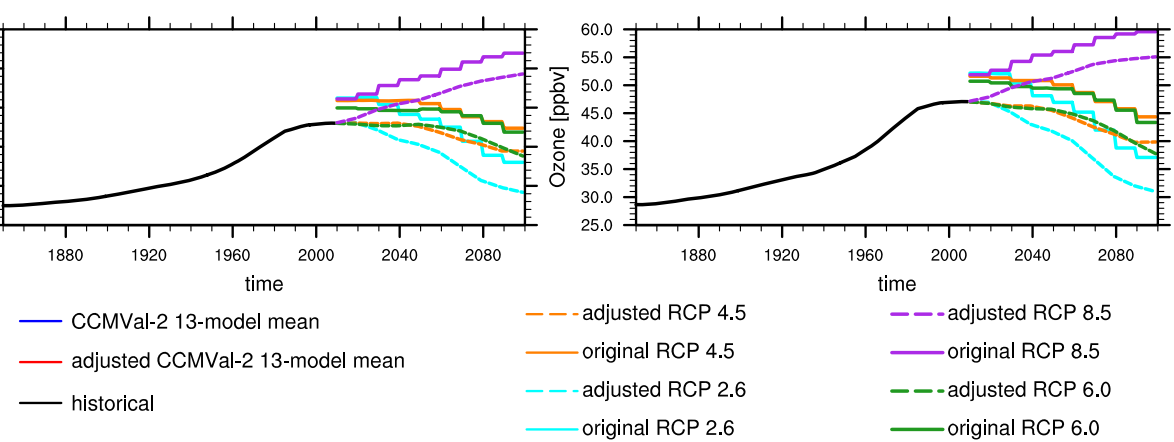

Fig. 2. Upper row: time series of annual mean northern midlatitude ozone [ppmv] at $5 \mathrm{hPa}$ (left) and $50 \mathrm{hPa}$ (right) from the historical ozone database (black line, derived from observations), the future stratospheric time series under the SRES A1B GHG scenario (blue line, derived from CCMVal-2 13-model mean), and the merged dataset (red line). Lower row: time series of annual mean northern midlatitude ozone [ppbv] at $500 \mathrm{hPa}$ (left) and $700 \mathrm{hPa}$ (right) from the historical ozone database (black line, derived from PUCCINI and CAM3.5 model mean, the future tropospheric ozone projections for the four RCPs (colored solid lines, CAM3.5 simulation), and the merged dataset (colored dashed lines).

Table 3. Date of return to 1980 column and $50 \mathrm{hPa}$ ozone in the AC\&C/SPARC ozone database compared to the 1980 baseline-adjusted time series of Eyring et al. (2010a). The range in brackets in the right most columns provides the uncertainty range from the 18 CCMs in Eyring et al. (2010a). For the AC\&C ozone database, the stratospheric ozone is shown since tropospheric column ozone differs substantially among the RCP scenarios (see Eyring et al., 2010b).

\begin{tabular}{lllll}
\hline Region & $\begin{array}{l}\text { AC\&C/SPARC } \\
\text { Stratospheric } \\
\text { column ozone }\end{array}$ & $\begin{array}{l}\text { Eyring et al. } \\
(2010 \mathrm{a}) \\
\text { Total column } \\
\text { ozone }\end{array}$ & $\begin{array}{l}\text { AC\&C/SPARC } \\
\text { Ozone at } \\
50 \mathrm{hPa}\end{array}$ & $\begin{array}{l}\text { Eyring et al. } \\
\text { (2010a) } \\
\text { Ozone at } \\
50 \mathrm{hPa}\end{array}$ \\
\hline $\begin{array}{l}\text { Tropics annual } \\
\text { mean }\end{array}$ & - & 2042 & - & - \\
$\begin{array}{l}\text { Midlatitude NH } \\
\text { annual mean }\end{array}$ & 2054 & $2021,-]$ & & {$[-,-]$} \\
$\begin{array}{l}\text { Midlatitude SH } \\
\text { annual mean }\end{array}$ & 2031 & {$[2014,2029]$} & - & 2043 \\
$\begin{array}{l}\text { Antarctic } \\
\text { October mean }\end{array}$ & 2045 & 2035 & 2049 & {$[2024,-]$} \\
$\begin{array}{l}\text { Arctic March } \\
\text { mean }\end{array}$ & 2031 & {$[2030,2040]$} & & 2058 \\
\hline
\end{tabular}




\subsection{Merged historical and future ozone database}

To merge the historical dataset with the future data set, differences in the annual cycle for 2009 are calculated and then subtracted from all time series in the future data set in both the troposphere and stratosphere. This calculation is done for all latitudes, longitudes and levels of the database. In addition, the ozone mixing ratios have been vertically interpolated from the original pressure levels to the final pressure levels that are defined in the database. This vertical interpolation was done with the function int $2 p$ of the NCAR Command Language (NCL) software (http://www.ncl.ucar. edu/Document/Functions/Built-in/int2p.shtml) using the option of logarithmic interpolation. Vertical smoothing was not applied.

As an example, the upper row of Fig. 2 shows the time series of northern midlatitude ozone from the CCMVal-2 multimodel mean compared to the historical ozone database that is based on observations and the merged dataset for two selected stratospheric levels ( 5 and $50 \mathrm{hPa})$. The offset that exists between the multi-model mean and the observations in 2009 is removed in the merged database. The interannual variability decreases in the stratosphere since solar variability is not considered in the future CCMVal-2 simulations and since the multi-model mean timeseries has been smoothed before the merging (Sect. 2.2). The merging works well in cases where the simulated trend between 1960 and 2009 agrees well with observations. In the northern midlatitudes, this is the case for the $5 \mathrm{hPa}$ level, but not for the $50 \mathrm{hPa}$ level, where the observed trend is larger (see Chapter 9 of SPARC CCMVal, 2010 and Austin et al., 2010). As a result, while in the CCMVal-2 13-model mean (blue line) ozone at $50 \mathrm{hPa}$ returns to 1980 levels, this is not the case in the merged database. The differences in ozone return dates at $50 \mathrm{hPa}$ and for column ozone are summarized in Table 3 . The merging results in differences between the ozone return dates derived from the multi-model mean CCMVal-2 time series (Eyring et al., 2010a) and the AC\&C/SPARC ozone database. These differences are largest in the northern midlatitudes while in all other regions the return dates are within the uncertainty range derived by Eyring et al. (2010a).

The lower row of Fig. 2 shows two tropospheric levels (500 and $700 \mathrm{hPa}$ ). Since the GISS-PUCCINI simulation is not continued into the future, there is also a small shift between the merged simulation (colored dashed line) and the one by CAM3.5 (colored solid lines). The resulting merged database is also shown for one tropospheric $(500 \mathrm{hPa})$ and one stratospheric $(50 \mathrm{hPa})$ level for different regions in Fig. 3. Animations that show decadal averages for total and tropospheric column ozone from the 1850 s to the 2090s for the four RCPs can be found in the Supplement.

It should be noted that the resulting merged ozone database has some internal inconsistencies, which are briefly summarized below. These inconsistencies need to be consid- ered while interpreting CMIP5 models that are forced with the ozone dataset described here:

- The historical database is derived from observations in the stratosphere but consists of a 2-model mean in the troposphere, see discussion above.

- The ozone database consists of a zonal mean ozone field (latitude, altitude) in the stratosphere, but is a full three dimensional field (latitude, longitude, altitude) in the troposphere.

- The stratospheric ozone database includes solar variability in the past since the past is based on observations, but does not include solar variability in the future.

- While the future tropospheric database is consistent with the four RCPs, the stratospheric ozone projections are based on the SRES A1B GHG scenario (i.e. only one scenario in the future). This approach was taken since at the time the ozone database was required for the CMIP5 activities (September 2009), a multi-model mean existed only for this single GHG scenario. Implications of different GHG scenarios on stratospheric ozone are discussed in Eyring et al. (2010b). With a small set of models that performed the individual simulations, it was found that differences in stratospheric column ozone among the six GHG scenarios considered (SRES A1B, SRES B2, SRES A2, plus the three RCPs 8.5, 4.5 and 2.6) are largest over northern midlatitudes ( $\sim 20$ DU by 2100$)$ and in the Arctic ( $\sim 40$ DU by 2100$)$ with divergence mainly in the second half of the 21 st century.

\section{Results and evaluation}

Before showing the radiative forcing results in Sect. 4, we describe aspects of the merged ozone database including total column ozone (Sect. 3.1), tropospheric column ozone (Sect. 3.2), surface ozone (Sect. 3.3), and vertical profiles of ozone (Sect. 3.4). Since the tropospheric part of the ozone database is created from model simulations, we also evaluate the results by comparing them to satellite, ozonesonde and in situ observations. The CCMs that are used for the stratospheric ozone projections under the SRES A1B GHG scenario have been extensively evaluated and analysed in the existing literature (SPARC CCMVal, 2010).

\subsection{Total column ozone}

Figure 4 shows decadal averages of zonal mean total column ozone for representative decades of the historical combined stratospheric and tropospheric database. The wellknown features of highest total column ozone in Northern and Southern Hemisphere spring, low ozone values with a 

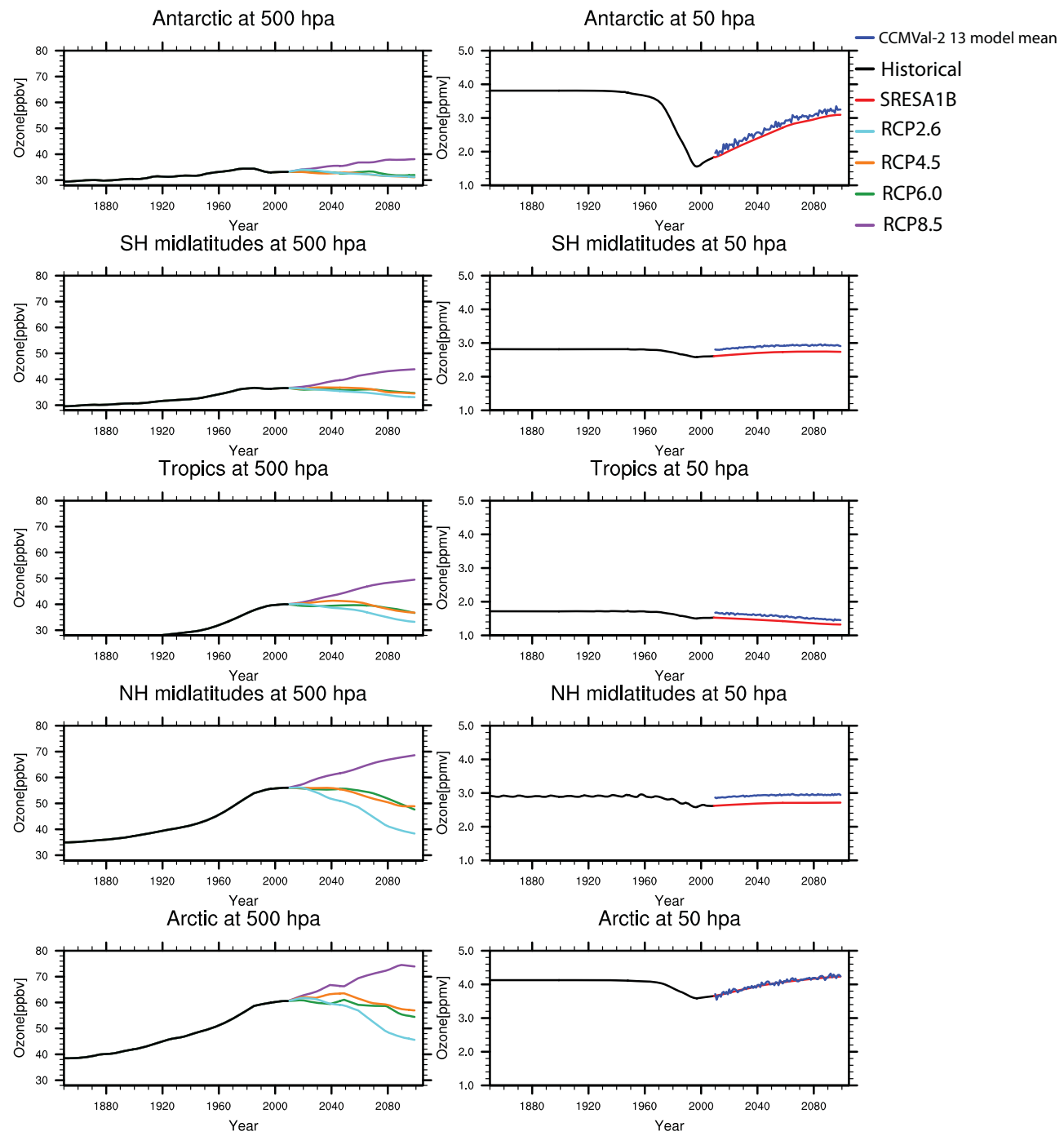

Fig. 3. Annual time series at $500 \mathrm{hPa}$ (left) and $50 \mathrm{hPa}$ (right) in various regions (spring-time Arctic and Antarctic, annual mean northern and southern midlatitudes, annual mean tropics).

small seasonal cycle in the tropics and a relative ozone maximum in the midlatitudes of the Southern Hemisphere in late winter/early spring are represented in the pre-ozone hole period until the 1960s, with very little differences in the decadal means of the 1850s to the 1960s. From the 1970s onwards, the dominant change in total column ozone is the appearance of the minimum ozone column above the Antarctic due to increases in ODSs. In addition, recent Arctic total column ozone in spring is also smaller than before 1970 .

The 20-yr mean climatological total column ozone from 1980 to 1999 from the AC\&C/SPARC ozone database generally compares well to the NIWA combined total column ozone database (Bodeker et al., 2005) and to TOMS observations (Stolarski and Frith, 2006), see Fig. 5. It should be noted that total column ozone in the historical time series is mainly dominated by stratospheric ozone (i.e. not tropospheric ozone) and thus this is mainly a comparison between the NIWA combined total column ozone data, TOMS observations and the SAGE I+II satellite observations. As described in Hassler et al. (2009), total column ozone in the Antarctic in the Randel and Wu (2007) dataset (i.e. in the AC\&C/SPARC ozone database) is higher than in the NIWA and TOMS data sets because in this region the Randel and $\mathrm{Wu}$ (2007) database is based only on the ozonesondes from the Syowa station located at $69^{\circ} \mathrm{S}$. This station is not in the centre of the vortex but is close to the vortex edge and therefore the ozone measured there is occasionally indicative of midlatitude rather than polar air. This is confirmed by Solomon et al. (2005) who show that the Syowa station displays smaller October mean ozone depletion than the station at the South Pole. With respect to the NIWA observations, total column ozone of the AC\&C/SPARC database averaged over the period 1980-1999 has a slightly larger bias over Antarctica in spring than does the CCMVal-2 multi-model 


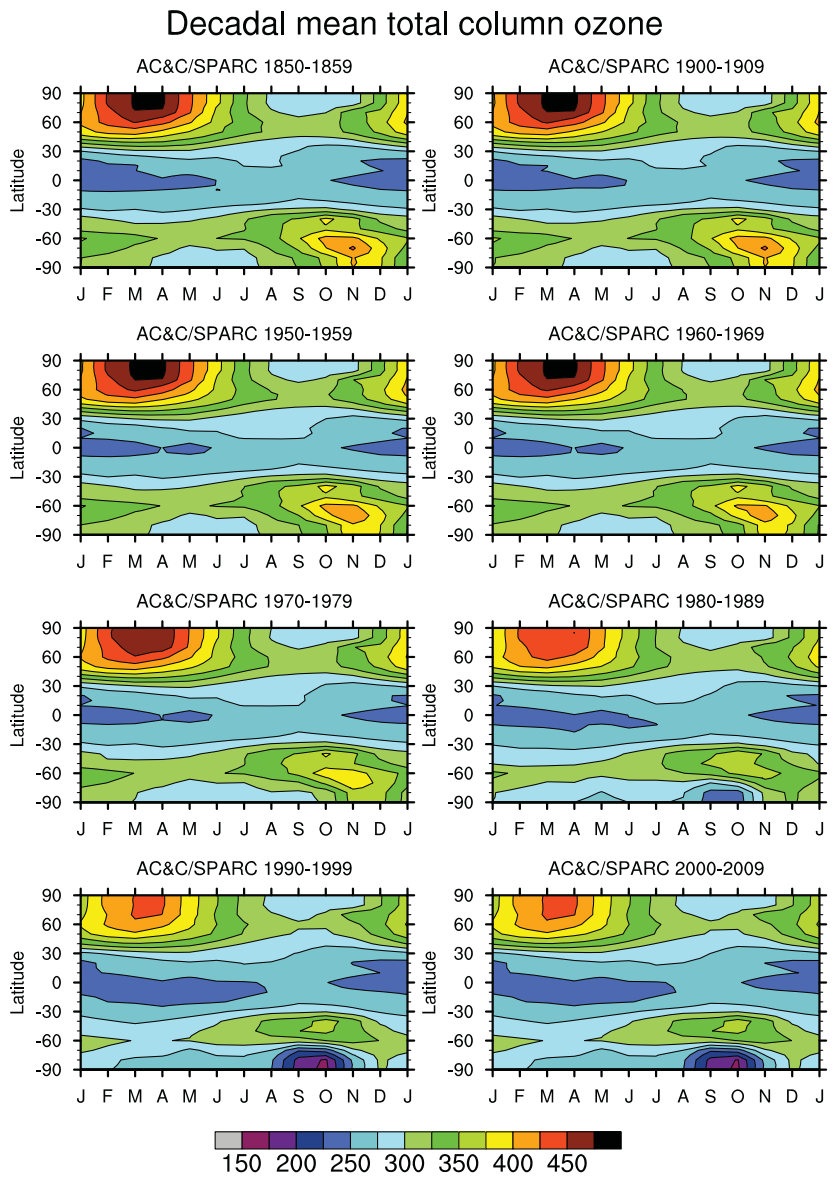

Fig. 4. Decadal mean total column ozone [DU] in the historical part of the ozone database. The decades span the period from the $1850 \mathrm{~s}$ (top left) to the 2000s (bottom right).

mean (Fig. 6a-d). The historical changes in total column ozone are dominated by responses to ODSs, resulting in peak ozone depletion around $2000(\sim 80 \mathrm{DU}$ lower than its 1980 value), which is in reasonably good agreement with the NIWA observations (Fig. 6e). The decline in springtime Antarctic total column ozone is followed by a slow and steady increase until 2100 (see light blue curve in upper right panel of Fig. 7).

Arctic total column ozone in spring is higher than in the NIWA and TOMS data sets (Fig. 5). In this case the differences are relatively small (less than $6 \%$ in April). The Randel and $\mathrm{Wu}(2007)$ values, and thus the ozone database values in the Arctic, are based on the Resolute ozonesonde measurements at $75^{\circ} \mathrm{N}$. Spring-time Arctic total column ozone evolves similarly to spring-time Antarctic ozone, but with smaller ozone losses during the peak ozone depletion period ( $\sim 23$ DU smaller than the 1980 value). In addition, ozone increases significantly above 1960 values by the end of the 21st century in the SRES A1B simulation, due to GHGinduced strengthening of the Brewer-Dobson circulation (see dark blue curve in upper right panel of Fig. 7).
As noted in previous studies (e.g. Austin et al., 2010; SPARC CCMVal, 2010; Eyring et al., 2010a), the evolution of tropical total (or stratospheric) column ozone depends on the balance between the increase in upper stratospheric concentrations (due to $\mathrm{CO}_{2}$-induced stratospheric cooling which increases ozone) and the decrease in lower stratospheric concentrations (due to projected increases in tropical upwelling, see also Fig. 3). As a result the projected changes are in general small compared to extra-tropical regions $(\sim 3 \mathrm{DU})$. Because ozone averaged over midlatitudes first decreases until around 2000 and then increases again in the upper and lower stratosphere over the 21 st century (see also Fig. 3), a similar evolution is projected for midlatitude stratospheric column ozone, with the minimum in both hemispheres being reached by $\sim 2000$ followed by a steady and significant increase (see green and black curves in upper and lower left panels of Fig. 7).

\subsection{Tropospheric column ozone}

In Fig. 8 tropospheric column ozone values averaged over the period 2005 to 2009 are compared to values derived from OMI and MLS instruments on board the Aura satellite (Ziemke et al., 2011; source: http://acdb-ext.gsfc.nasa. gov/Data_services/cloud_slice/new_data.html). Tropospheric ozone column in the ACC/SPARC ozone database is slightly lower than the OMI and MLS observations (by less than 5 DU, see upper row in Fig. 8). The local maximum between Africa and South America, a region that is affected by biomass burning, is reproduced. The lower row in Fig. 8 shows that the annual cycle in tropospheric column ozone is in general well reproduced by the AC\&C/SPARC ozone database. However, the maximum during spring in the Southern Hemisphere and the maximum during spring/summer in the Northern Hemisphere are underestimated. This seasonal increase in tropospheric column ozone is the effect of both increased photo-chemistry and dynamics (stratosphere-troposphere exchange) (de Laat et al., 2005; Ziemke et al., 2011).

Tropospheric column ozone shows a historical change between 1850 and 2000 of around 7.3 $\pm 0.1 \mathrm{DU}$, which is $21-$ $35 \%$ less than the model-range (8.9-10.8 DU for chemistryclimate models with tropospheric and stratospheric chemistry) documented in Gauss et al. (2006). The models in Gauss et al. (2006) used a variety of estimates for year 2000 emissions, and methane was set at 1740-1760 ppb (see their Table 2). For 1850, all anthropogenic emissions were set to zero, biomass burning emissions were reduced by $90 \%$, and methane was set at $792 \mathrm{ppb}$. The methane change applied by Gauss et al. (2006) is similar to that used here (Fig. 1b), but the 1850-2000 changes in emissions, especially biomass burning, are generally smaller in our study (e.g. overall $\mathrm{NO}_{\mathrm{x}}$ emissions increase by $32 \mathrm{Tg}(\mathrm{N}) \mathrm{yr}^{-1}$ here, but by an average of $38 \mathrm{Tg}(\mathrm{N}) \mathrm{yr}^{-1}$ in the models used in Gauss et al., 2006), and this is probably the main reason why the tropospheric 

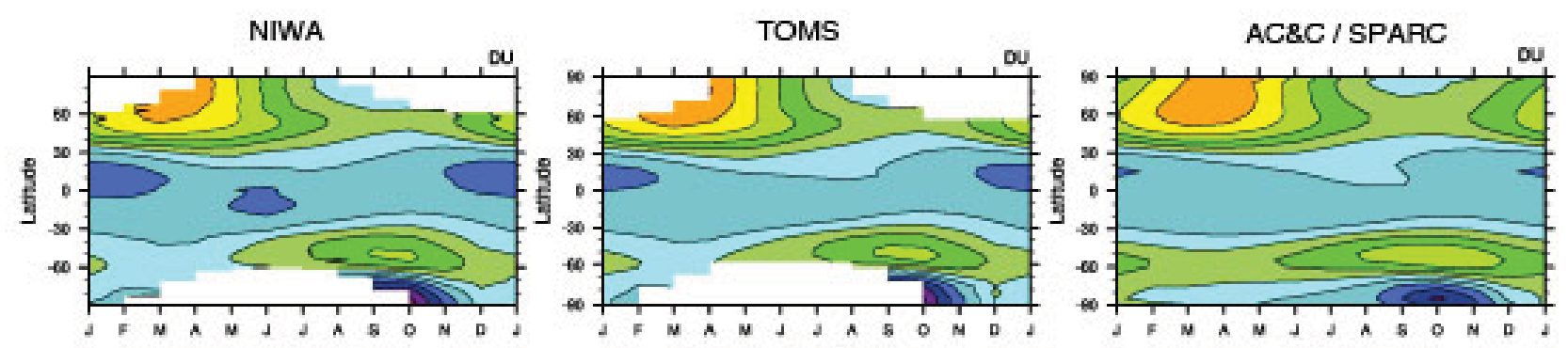

150175200225250275300325350375400425450475

Fig. 5. Total column ozone climatologies (1980 to 1999) for the AC\&C/SPARC ozone database compared to the NIWA combined total column ozone database (Bodeker et al., 2005) and TOMS (Stolarski and Frith, 2006).
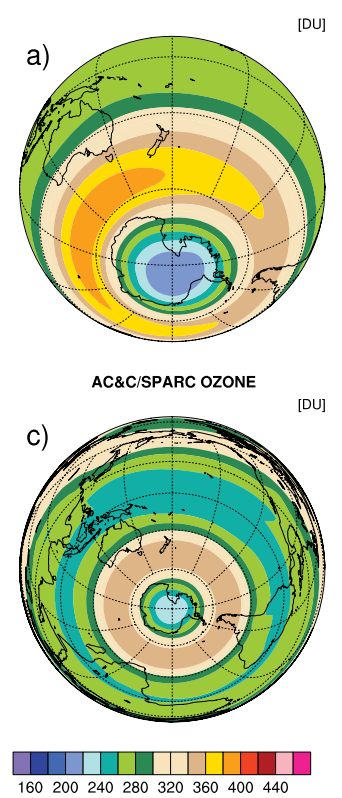

e) Antarctica SON

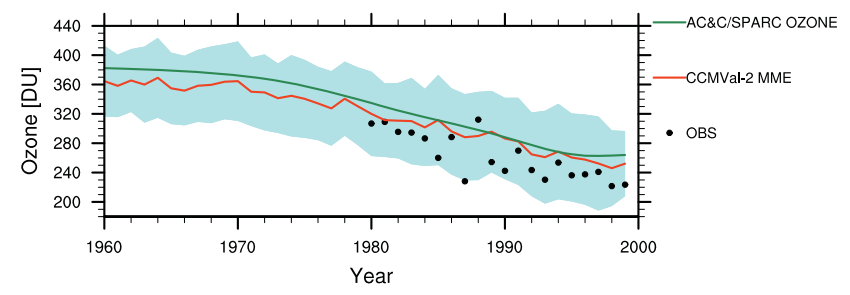

Fig. 6. September to November total column ozone mean (19801999) from the CCMVal-2 multi-model mean (a) and the bias of it from the NIWA database (b). (c, d) Same as (a, b), but for the AC\&C/SPARC ozone database; (e) time series of total column ozone over Antarctica (averaged from 60-90 ${ }^{\circ} \mathrm{S}$ ) from 1960 to 2000 for the CCMVal-2 multi-model mean (red line) and standard deviation (blue shaded area) in comparison to the AC\&C/SPARC ozone database (green line) and observations from the NIWA database (black dots).
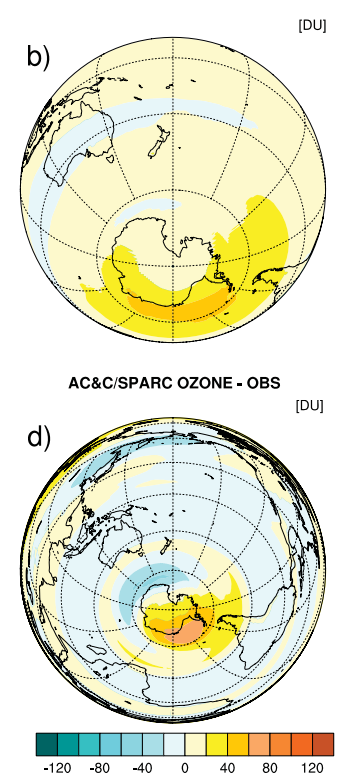
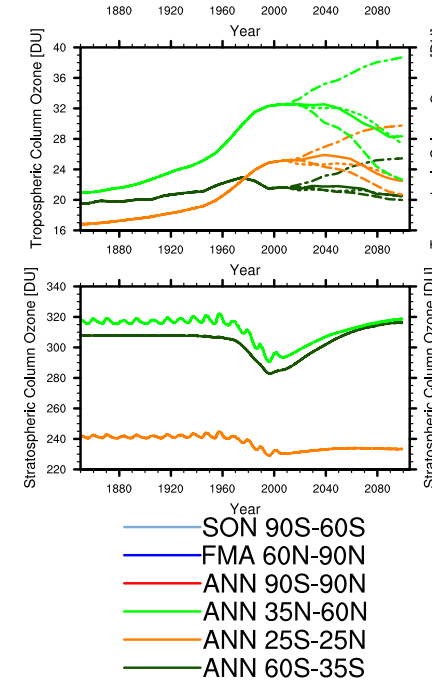

Ozone timeseries for different latitude bands
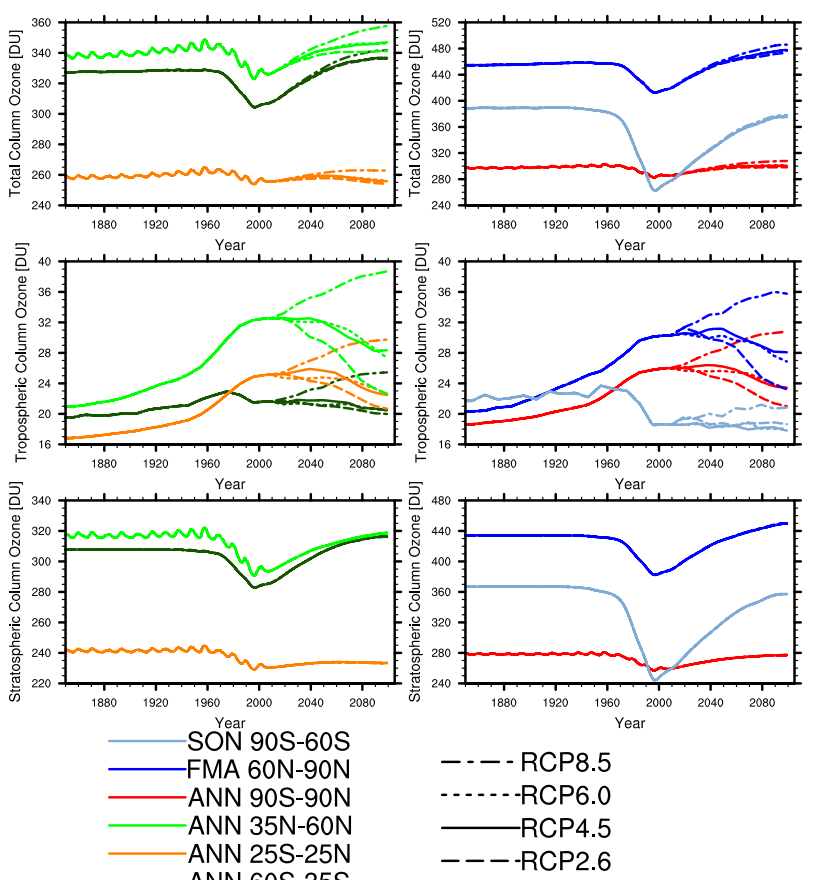

Fig. 7. Timeseries of total column ozone (upper row), tropospheric column ozone (middle row) and stratospheric column ozone (lower row) averaged over different latitude bands: Arctic $\left(60-90^{\circ} \mathrm{N}\right)$, Antarctic $\left(60-90^{\circ} \mathrm{S}\right)$, northern midaltitudes $\left(35-60^{\circ} \mathrm{S}\right)$, southern midlatitudes $\left(35-60^{\circ} \mathrm{N}\right)$, tropics $\left(25^{\circ} \mathrm{N}-25^{\circ} \mathrm{S}\right)$, and global mean $\left(90^{\circ} \mathrm{N}-90^{\circ} \mathrm{S}\right)$. The four future scenarios are RCP 2.6 (dashed lines), RCP 4.5 (solid lines), RCP 6.0 (dotted lines), and RCP 8.5 (dashed-dotted lines). 


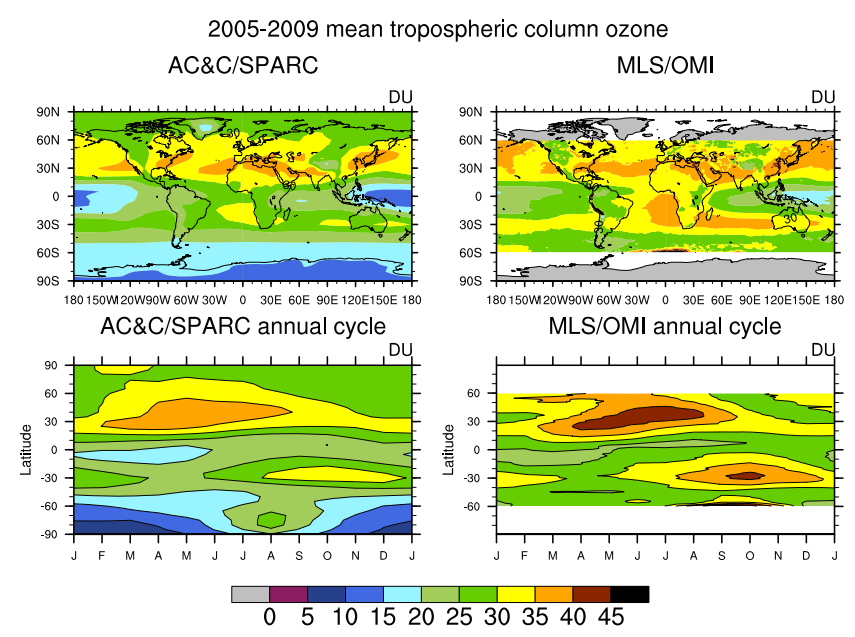

Fig. 8. Tropospheric column ozone averaged between 2005 and 2009 from the AC\&C/SPARC ozone database compared to MLS/OMI observations (from Ziemke et al., 2011).

ozone increase reported here is less than in most previous studies.

Trends in tropospheric and total column ozone between the 2010s and the 2090s are summarized in Table 4. Unlike in previous studies that assessed CCMVal-2 SRES A1B simulations (Austin et al., 2010; SPARC CCMVal, 2010; Eyring et al., 2010a), trends in tropospheric column ozone contribute substantially to the trends in total column ozone in the future CAM3.5 RCP simulations. Therefore, future total column ozone in various regions (upper row in Fig. 7) varies among the scenarios although the stratospheric ozone projections are based on a single future scenario (lower row in Fig. 7). These variations result from tropospheric column ozone differences among the RCPs (middle row in Fig. 7), which are large in the northern midlatitudes and in the Arctic ( $\sim 16$ and 13 DU by 2100 , respectively) and smaller over Antarctica, southern midlatitudes, and the tropics $(\sim 3,5$ and 9 DU by 2100 , respectively). While the changes in the emissions of important ozone precursors $\left(\mathrm{NO}_{\mathrm{x}}, \mathrm{CO}, \mathrm{VOCs}\right)$ are not hugely different between RCPs (except $\mathrm{NO}_{\mathrm{x}}$ for which the RCP 8.5 emissions in 2100 are $\sim 30 \%$ larger than the other RCPs), there are wide variations (a factor of 3 between RCP 2.6 and RCP 8.5 ) between the estimated mixing ratios for methane (van Vuuren et al., 2010). Therefore, as noted by Lamarque et al. (2010b), the large variations in tropospheric column ozone among the four RCPs are likely due to the different methane mixing ratios that strongly impact tropospheric ozone, much more than the difference in $\mathrm{NO}_{\mathrm{x}}$ emissions (see also Fiore et al., 2002). The differences in methane are therefore the main driver of the tropospheric ozone changes in the 21st century. In addition, Fig. 9 shows a map of tropospheric column ozone for selected decades of the historical and future database. The overall evolution is similar to that of the $500 \mathrm{hPa}$ level shown in Fig. 3. Similar to the time series of ozone at $500 \mathrm{hPa}$ the spread between the RCP scenarios is larger in the Northern than in the Southern Hemisphere. Ozone in the RCP 8.5 scenario increases globally, with largest increases around $30^{\circ} \mathrm{N}$ over Europe, Africa and Far East Asia.

\subsection{Surface ozone}

Figure 10 shows decadal mean surface ozone in the past (1940s and 2000s) and future (2050s and 2090s). In the past, surface ozone has increased over the globe due to the increase in ozone precursors (see Fig. 1), with largest increases in the northern midlatitudes over land. In the future scenarios, the reduction in $\mathrm{NO}_{\mathrm{x}}$ emissions in the RCP 2.6, 4.5 and 6.0 scenario from around $125 \mathrm{Tg}\left(\mathrm{NO}_{2}\right) \mathrm{yr}^{-1}$ in 2000 to around $60 \mathrm{Tg}\left(\mathrm{NO}_{2}\right) \mathrm{yr}^{-1}$ in 2100 , along with the decrease in $\mathrm{CO}$ and VOC emissions and the change in methane concentrations (see Fig. 1) results in a reduction of surface ozone by the 2090s compared to the 2000s for all RCPs (Fig. 10). In contrast to tropospheric column ozone which is continuously increasing in the RCP 8.5 scenario (Fig. 9), surface ozone is decreasing in RCP 8.5. In the last decade of the 21st century, surface ozone in the RCP 6.0 scenario is slightly higher than in the RCP 8.5 scenario, partly as a response to the higher VOC and CO emissions in the RCP 6.0 scenario at the end of the 21 st century. However, this also reflects the larger magnitude of climate change in RCP 8.5, and the associated negative feedbacks of climate change on surface ozone, in particular due to increases in absolute humidity, and hence ozone destruction (e.g. Johnson et al., 2001). It should be noted that the changes in surface ozone in the RCP 8.5 scenario are much smaller than those projected by model simulations based on the SRES A2 $\mathrm{NO}_{\mathrm{x}}$ scenario (Prather et al., 2003), where $\mathrm{NO}_{\mathrm{x}}$ emissions were continuously increasing up to $109.2 \mathrm{TgN} \mathrm{yr}^{-1}$ in $2100\left(358.8 \mathrm{TgNO}_{2} \mathrm{yr}^{-1}\right)$ by 2100 (IPCC, 2001). The large increases in $\mathrm{NO}_{\mathrm{x}}$ projected in the SRES A2 scenario are now thought to be highly unlikely, given global concerns about air quality and the pervasive uptake of measures to reduce air pollution (e.g. Dentener et al., 2005; Cofala et al., 2007). The Prather et al. (2003) study also did not include any climate change feedbacks on surface ozone.

\subsection{Vertical ozone profiles}

To further evaluate the AC\&C/SPARC ozone database in the troposphere, we also compare the vertical profiles to ozonesondes at selected stations from Logan et al. (1999) and to in situ measurements for selected sites from Emmons et al. (2000).

The first column in Fig. 11 shows the annual cycle in ozonesonde observations from Logan et al. (1999), and the second column the equivalent plot from the AC\&C/SPARC ozone database. The final column compares all points, with bars indicating the standard deviation in the observations. 
Table 4. Trends (2090s-2010s) in total and tropospheric column ozone in the four RCPs.

\begin{tabular}{|c|c|c|c|c|c|c|c|}
\hline & & $\begin{array}{l}\text { Spring- } \\
\text { time Arctic } \\
(\text { FMA) } \\
\left(60^{\circ} \mathrm{N}-\right. \\
\left.90^{\circ} \mathrm{N}\right)\end{array}$ & $\begin{array}{l}\text { Spring- } \\
\text { time } \\
\text { Antarctic } \\
(\mathrm{SON}) \\
\left(90^{\circ} \mathrm{S}-\right. \\
\left.60^{\circ} \mathrm{S}\right)\end{array}$ & $\begin{array}{l}\text { Annual } \\
\text { mean } \\
\text { southern } \\
\text { midlati- } \\
\text { tudes } \\
\left(60^{\circ} \mathrm{S}-\right. \\
\left.35^{\circ} \mathrm{S}\right)\end{array}$ & $\begin{array}{l}\text { Annual } \\
\text { mean } \\
\text { northern } \\
\text { midlati- } \\
\text { tudes } \\
\left(35^{\circ} \mathrm{N}-\right. \\
\left.60^{\circ} \mathrm{N}\right)\end{array}$ & $\begin{array}{l}\text { Annual } \\
\text { mean } \\
\text { tropics } \\
\left(25^{\circ} \mathrm{S}-\right. \\
\left.25^{\circ} \mathrm{N}\right)\end{array}$ & $\begin{array}{l}\text { Annual } \\
\text { global } \\
\text { mean } \\
\left(90^{\circ} \mathrm{S}-\right. \\
\left.90^{\circ} \mathrm{N}\right)\end{array}$ \\
\hline \multirow[t]{3}{*}{ RCP 2.6} & $\begin{array}{l}\text { Total } \\
\text { Column } \\
\text { Ozone }\end{array}$ & $\begin{array}{l}56 \mathrm{DU} \\
(13 \%)\end{array}$ & $\begin{array}{l}104 \mathrm{DU} \\
(38 \%)\end{array}$ & $\begin{array}{l}29 \mathrm{DU} \\
(10 \%)\end{array}$ & $\begin{array}{l}14 \mathrm{DU} \\
(4 \%)\end{array}$ & $\begin{array}{l}-2 \mathrm{DU} \\
(-1 \%)\end{array}$ & $\begin{array}{l}12 \mathrm{DU} \\
(4 \%)\end{array}$ \\
\hline & $\begin{array}{l}\text { Tropos. } \\
\text { Column } \\
\text { Ozone }\end{array}$ & $\begin{array}{l}-7 \text { DU } \\
(-22 \%)\end{array}$ & $\begin{array}{l}0 \mathrm{DU} \\
(0 \%)\end{array}$ & $\begin{array}{l}-2 \mathrm{DU} \\
(-7 \%)\end{array}$ & $\begin{array}{l}-9 \mathrm{DU} \\
(-29 \%)\end{array}$ & $\begin{array}{l}-4 \mathrm{DU} \\
(-17 \%)\end{array}$ & $\begin{array}{l}-5 \mathrm{DU} \\
(-18 \%)\end{array}$ \\
\hline & $\begin{array}{l}\text { Stratos. } \\
\text { Column } \\
\text { Ozone }\end{array}$ & $\begin{array}{l}63 \mathrm{DU} \\
(16 \%)\end{array}$ & $\begin{array}{l}104 \mathrm{DU} \\
(40 \%)\end{array}$ & $\begin{array}{l}31 \mathrm{DU} \\
(11 \%)\end{array}$ & $\begin{array}{l}23 \mathrm{DU} \\
(8 \%)\end{array}$ & $\begin{array}{l}2 \mathrm{DU} \\
(1 \%)\end{array}$ & $\begin{array}{l}17 \mathrm{DU} \\
(7 \%)\end{array}$ \\
\hline \multirow[t]{3}{*}{ RCP 4.5} & $\begin{array}{l}\text { Total } \\
\text { Column } \\
\text { Ozone }\end{array}$ & $\begin{array}{l}61 \mathrm{DU} \\
(15 \%)\end{array}$ & $\begin{array}{l}103 \mathrm{DU} \\
(38 \%)\end{array}$ & $\begin{array}{l}30 \mathrm{DU} \\
(10 \%)\end{array}$ & $\begin{array}{l}19 \mathrm{DU} \\
(6 \%)\end{array}$ & $\begin{array}{l}0 \mathrm{DU} \\
(0 \%)\end{array}$ & $\begin{array}{l}15 \mathrm{DU} \\
(5 \%)\end{array}$ \\
\hline & $\begin{array}{l}\text { Tropos. } \\
\text { Column } \\
\text { Ozone }\end{array}$ & $\begin{array}{l}-2 \mathrm{DU} \\
(-7 \%)\end{array}$ & $\begin{array}{l}-1 \mathrm{DU} \\
(-3 \%)\end{array}$ & $\begin{array}{l}-1 \mathrm{DU} \\
(-5 \%)\end{array}$ & $\begin{array}{l}-4 \mathrm{DU} \\
(-13 \%)\end{array}$ & $\begin{array}{l}-2 \mathrm{DU} \\
(-10 \%)\end{array}$ & $\begin{array}{l}-2 \mathrm{DU} \\
(-9 \%)\end{array}$ \\
\hline & $\begin{array}{l}\text { Stratos. } \\
\text { Column } \\
\text { Ozone }\end{array}$ & $\begin{array}{l}63 \mathrm{DU} \\
(16 \%)\end{array}$ & $\begin{array}{l}104 \mathrm{DU} \\
(40 \%)\end{array}$ & $\begin{array}{l}31 \mathrm{DU} \\
(11 \%)\end{array}$ & $\begin{array}{l}23 \mathrm{DU} \\
(8 \%)\end{array}$ & $\begin{array}{l}2 \mathrm{DU} \\
(1 \%)\end{array}$ & $\begin{array}{l}17 \mathrm{DU} \\
(7 \%)\end{array}$ \\
\hline \multirow[t]{3}{*}{ RCP 6.0} & $\begin{array}{l}\text { Total } \\
\text { Column } \\
\text { Ozone }\end{array}$ & $\begin{array}{l}60 \mathrm{DU} \\
(14 \%)\end{array}$ & $\begin{array}{l}103 \mathrm{DU} \\
(38 \%)\end{array}$ & $\begin{array}{l}30 \mathrm{DU} \\
(10 \%)\end{array}$ & $\begin{array}{l}19 \mathrm{DU} \\
(6 \%)\end{array}$ & $\begin{array}{l}0 \mathrm{DU} \\
(0 \%)\end{array}$ & $\begin{array}{l}15 \mathrm{DU} \\
(5 \%)\end{array}$ \\
\hline & $\begin{array}{l}\text { Tropos. } \\
\text { Column } \\
\text { Ozone }\end{array}$ & $\begin{array}{l}-3 \text { DU } \\
(-10 \%)\end{array}$ & $\begin{array}{l}-1 \mathrm{DU} \\
(-3 \%)\end{array}$ & $\begin{array}{l}-1 \mathrm{DU} \\
(-5 \%)\end{array}$ & $\begin{array}{l}-4 \mathrm{DU} \\
(-13 \%)\end{array}$ & $\begin{array}{l}-2 \mathrm{DU} \\
(-10 \%)\end{array}$ & $\begin{array}{l}-2 \mathrm{DU} \\
(-9 \%)\end{array}$ \\
\hline & $\begin{array}{l}\text { Stratos. } \\
\text { Column } \\
\text { Ozone }\end{array}$ & $\begin{array}{l}63 \mathrm{DU} \\
(16 \%)\end{array}$ & $\begin{array}{l}104 \mathrm{DU} \\
(40 \%)\end{array}$ & $\begin{array}{l}31 \mathrm{DU} \\
(11 \%)\end{array}$ & $\begin{array}{l}23 \mathrm{DU} \\
(8 \%)\end{array}$ & $\begin{array}{l}2 \mathrm{DU} \\
(1 \%)\end{array}$ & $\begin{array}{l}17 \mathrm{DU} \\
(7 \%)\end{array}$ \\
\hline \multirow[t]{3}{*}{ RCP 8.5} & $\begin{array}{l}\text { Total } \\
\text { Column } \\
\text { Ozone }\end{array}$ & $\begin{array}{l}69 \mathrm{DU} \\
(17 \%)\end{array}$ & $\begin{array}{l}106 \mathrm{DU} \\
(39 \%)\end{array}$ & $\begin{array}{l}35 \mathrm{DU} \\
(11 \%)\end{array}$ & $\begin{array}{l}30 \mathrm{DU} \\
(9 \%)\end{array}$ & $\begin{array}{l}7 \mathrm{DU} \\
(3 \%)\end{array}$ & $\begin{array}{l}22 \mathrm{DU} \\
(8 \%)\end{array}$ \\
\hline & $\begin{array}{l}\text { Tropos. } \\
\text { Column } \\
\text { Ozone }\end{array}$ & $\begin{array}{l}6 \mathrm{DU} \\
(19 \%)\end{array}$ & $\begin{array}{l}2 \mathrm{DU} \\
(12 \%)\end{array}$ & $\begin{array}{l}4 \mathrm{DU} \\
(18 \%)\end{array}$ & $\begin{array}{l}7 \mathrm{DU} \\
(19 \%)\end{array}$ & $\begin{array}{l}5 \mathrm{DU} \\
(18 \%)\end{array}$ & $\begin{array}{l}5 \mathrm{DU} \\
(18 \%)\end{array}$ \\
\hline & $\begin{array}{l}\text { Stratos. } \\
\text { Column } \\
\text { Ozone }\end{array}$ & $\begin{array}{l}63 \mathrm{DU} \\
(16 \%)\end{array}$ & $\begin{array}{l}104 \mathrm{DU} \\
(40 \%)\end{array}$ & $\begin{array}{l}31 \mathrm{DU} \\
(11 \%)\end{array}$ & $\begin{array}{l}23 \mathrm{DU} \\
(8 \%)\end{array}$ & $\begin{array}{l}2 \mathrm{DU} \\
(1 \%)\end{array}$ & $\begin{array}{l}17 \mathrm{DU} \\
(7 \%)\end{array}$ \\
\hline
\end{tabular}

Where the model overpredicts (underpredicts) the observations by more than one standard deviation, the point is plotted in red (blue); these points are shown in the second column by the solid (dashed) contours. The approach that was taken in the comparison was to focus on the tropospheric ozonesonde observations with records of about $15 \mathrm{yr}$ (19801995) and locations that are representative of large geograph- ical regions not immediately influenced by nearby precursor sources (Churchill, Hohenpeissenberg and Aspendale). There is an excellent agreement between the ozonesonde measurements and the ozone database, with differences enclosed almost everywhere within 1 standard deviation of the observations. 


\section{Decadal mean tropospheric column ozone}

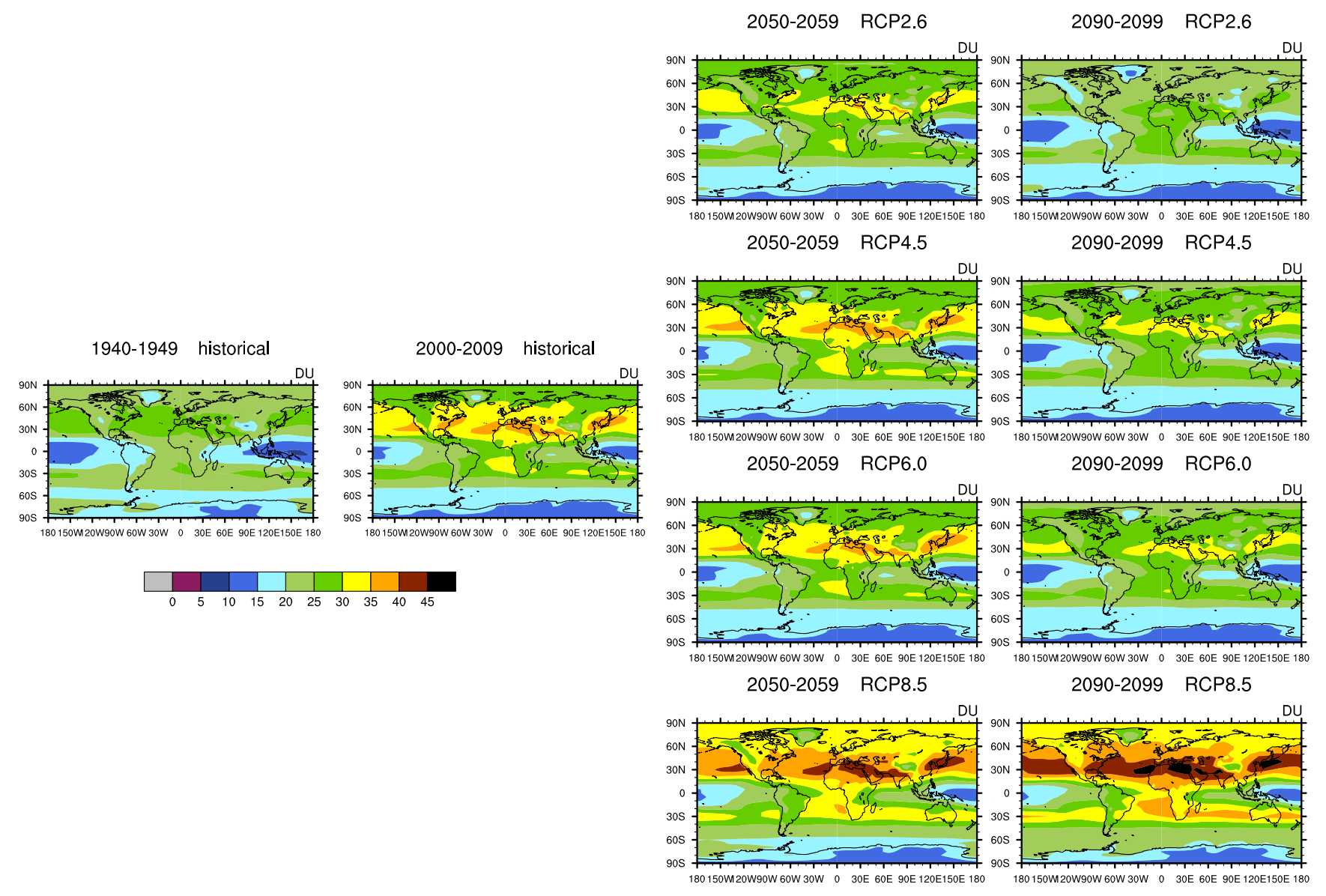

Fig. 9. Decadal mean tropospheric column in the historical database (left for the 1940s and 2000s) and the RCPs (right); from top to bottom: RCP 2.6, RCP 4.5, RCP 6.0 and RCP8.5 shown for the 2050s and 2090s.

Tropospheric ozone mixing ratios from a number of aircraft campaigns have been mapped onto a $5^{\circ}$ longitude by $5^{\circ}$ latitude grid by Emmons et al. (2000), with additional data from more recent campaigns (see http://gctm.acd.ucar.edu/ data), up to and including TRACE-P in 2001. Twelve different campaigns between 1985 and 2001 from 12 different regions have been selected for this comparison (Fig. 12). The comparison to in-situ measurements of vertical ozone profiles reveals that the AC\&C/SPARC ozone database is generally inside the interval that represents $90 \%$ of the observations with some deviations in regions of biomass burning. To summarise the comparison with aircraft data, we find generally good agreement between the database and observations. Exact agreement, especially near episodic sources of ozone precursors, cannot be expected from relatively coarse resolution global models with climates not constrained by meteorological re-analyses.
Turning now to the long-term changes in vertical profiles, Fig. 13a shows the percentage differences in the annual cycle between the $1960 \mathrm{~s}$ and the $2000 \mathrm{~s}$ at $80^{\circ} \mathrm{S}$. The region of maximum ozone depletion is localized between about 150 and $30 \mathrm{hPa}$ (approximately $14-25 \mathrm{~km}$ altitude) in October (up to $\sim 90 \%$ ), shown in detail in Fig. 14 where both the magnitude and the vertical profile of the depletion associated with the ozone hole over the South Pole is seen to agree well with that derived from ozonesondes. Ozone depletion begins during August corresponding to exposure of the cold winter air to sunlight (Sanders et al., 1993; Lee et al., 2000). During November at around $70 \mathrm{hPa}$ ozone starts to recover following the warming of the winter vortex and its subsequent breakup. At lower altitudes $(150 \mathrm{hPa})$ the largest ozone depletion occurs between December and January and the recovery starts later, in March. This lag between the middle and lower stratosphere is a consequence of the downward transport of ozone-poor air from above (Solomon et al., 2005). Figure $13 \mathrm{~b}$ displays percentage differences between 


\section{Decadal mean surface ozone}
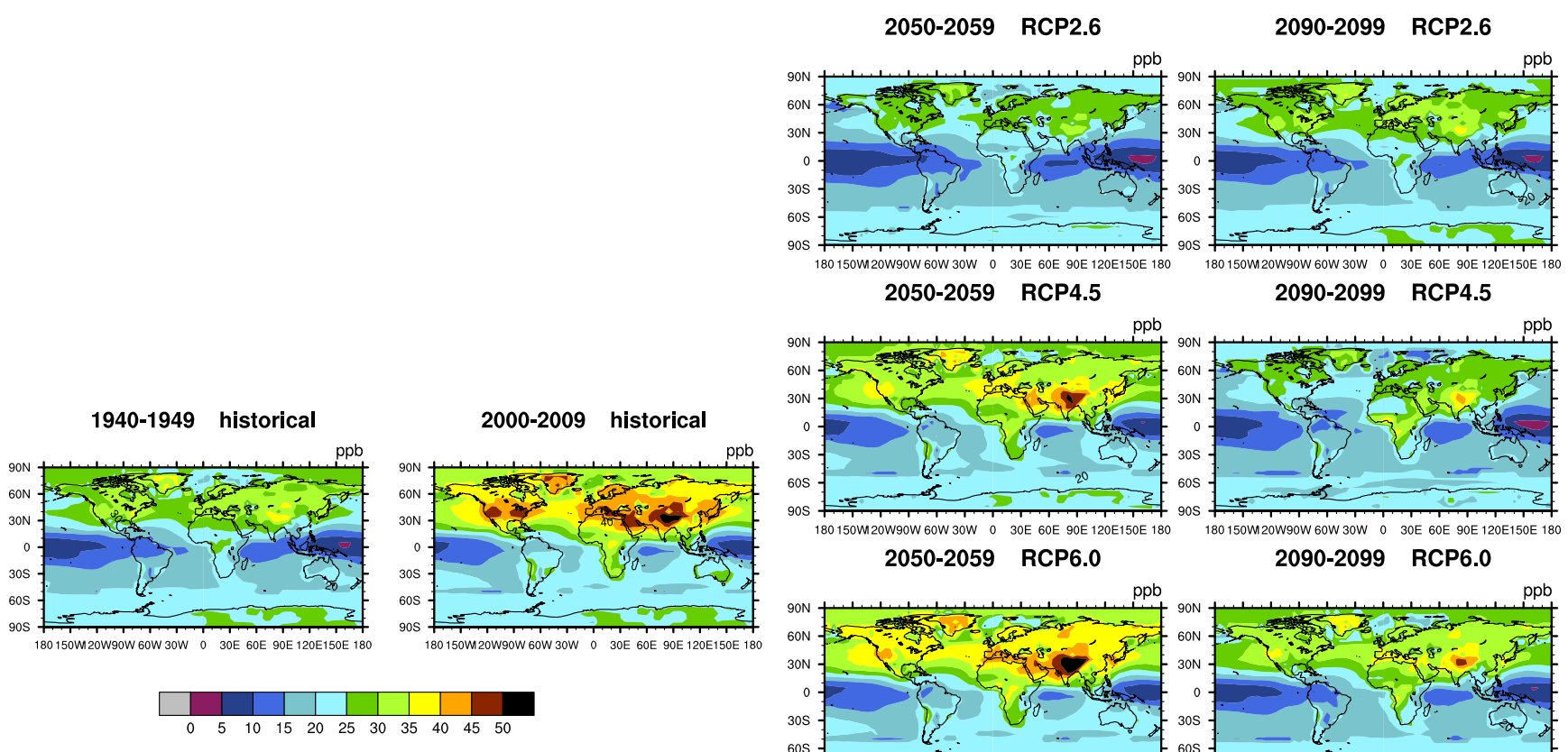

2050-2059 RCP4.5

2090-2099 RCP4.5
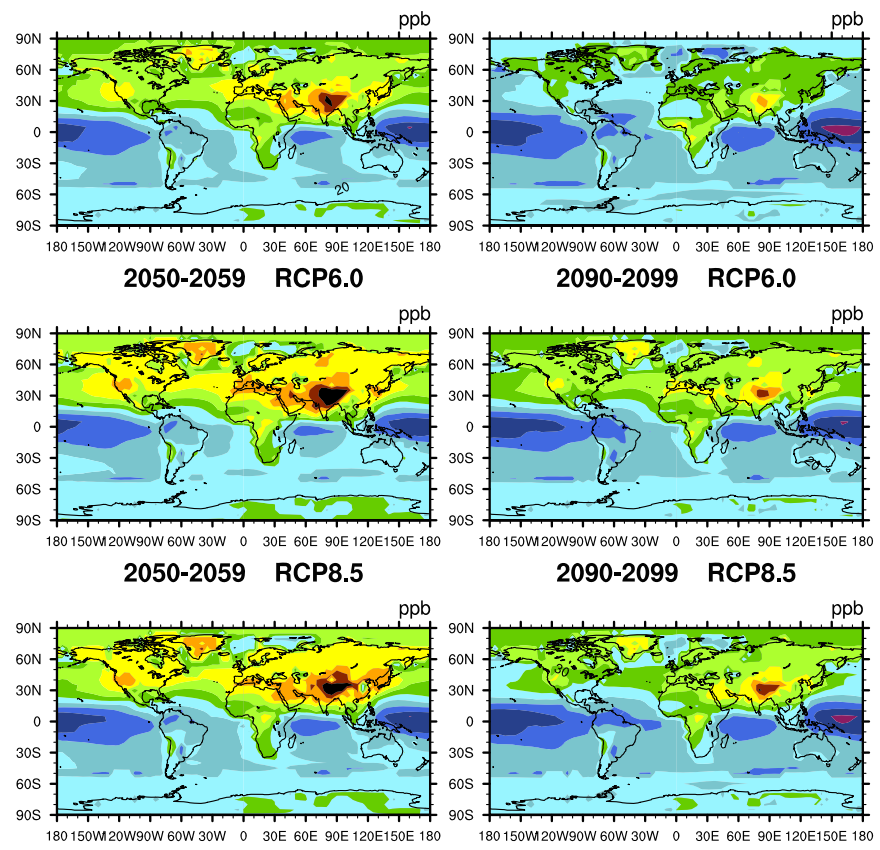

Fig. 10. As Fig. 9, but for decadal mean surface ozone.

the 1960s and the 2000s in zonal annual mean ozone. In the lower stratosphere the differences are negative over most of the latitudes, reaching around $-40 \%$ in the Antarctic at $100 \mathrm{hPa}$. From $40^{\circ} \mathrm{N}$ to $90^{\circ} \mathrm{N}$ ozone shows negative trends of about $15 \%$ between $300 \mathrm{hPa}$ and $50 \mathrm{hPa}$, which agrees well with the trends estimated from ozonesondes in Randel et al. (1999). The increase in ozone below the tropopause reaches $25-30 \%$ in the tropics and $15-25 \%$ in the northern hemispheric troposphere and is mainly attributable to the increase in ozone precursor emissions (Lamarque et al., 2005). Two maxima are exhibited: one close to the surface between $5^{\circ} \mathrm{N}$ and $20^{\circ} \mathrm{N}$ and the other at around $300 \mathrm{hPa}$ and $20^{\circ} \mathrm{N}$. According to Gauss et al. (2006), the near-surface increase in ozone is directly related to the increase of anthropogenic emission sources. The second maximum is probably related to convective uplift of the underlying maximum, but may also be partly related to climate change which tends to increase the exchange of ozone between the stratosphere and troposphere (Collins et al., 2003; Hegglin and Shepherd, 2009).
The corresponding vertical profiles of the projected future ozone changes for RCP 4.5 in the troposphere and SRES A1B in the stratosphere are shown in Figs. 13c, d and 14. As discussed earlier in the context of the stratospheric column changes (Fig. 7), the ozone hole largely but not entirely recovers to 1960 s values by the 2090s (Fig. 14). Midlatitude values in both hemispheres as well as polar lower stratospheric ozone considerably exceed 1960s values by the 2090s, while tropical lower stratospheric ozone continues to decline throughout the 21 st century, with the behaviour in both cases due to the enhanced Brewer-Dobson circulation. In the upper stratosphere, the 21 st century recovery exceeds the 20th century decline because of the additional ozone increase from $\mathrm{CO}_{2}$-induced upper stratospheric cooling.

Figure 13d indicates that ozone is projected to decline by $\sim 10-20 \%$ throughout much of the troposphere, under the RCP 4.5 scenario, especially near the surface in the Northern Hemisphere. The exception is the polar upper troposphere, which shows some increases in ozone close to the tropopause, associated with increased addition of ozone from 

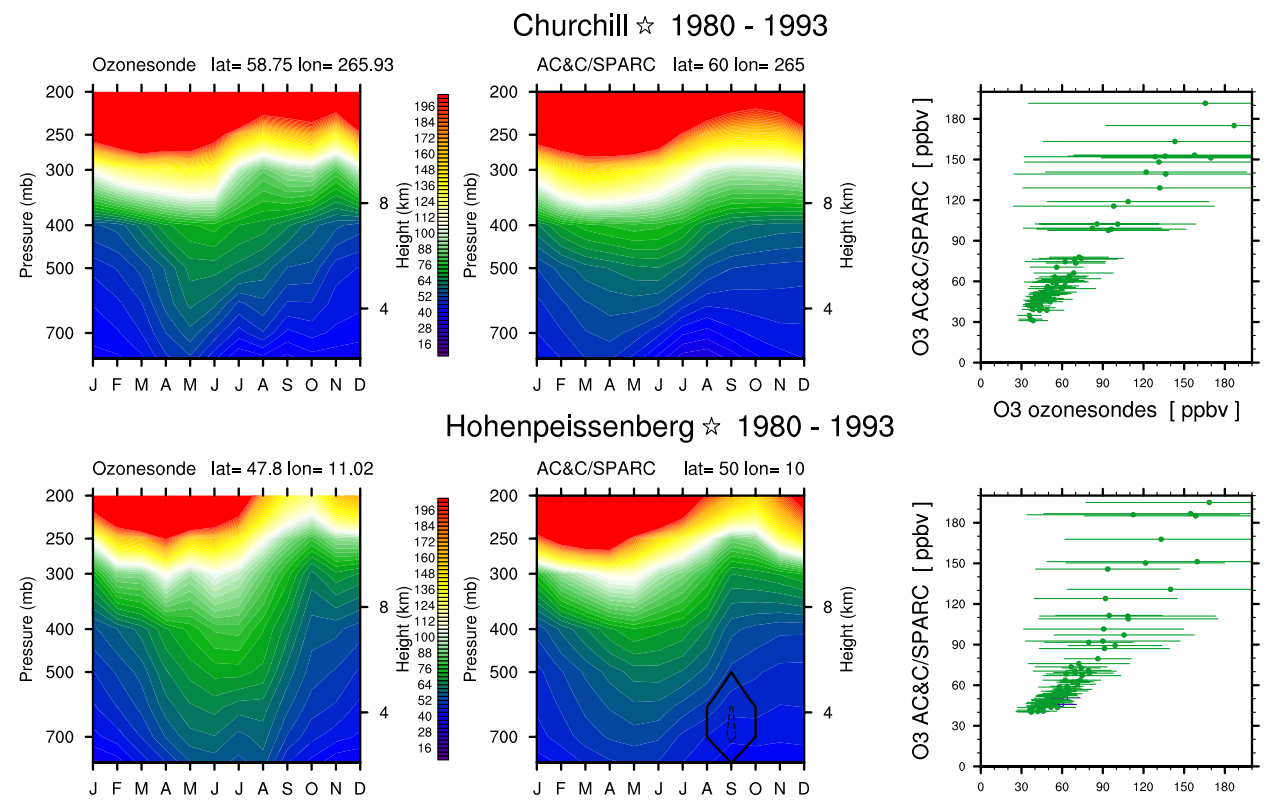

Hohenpeissenberg is $1980-1993$

O3 ozonesondes [ ppbv]
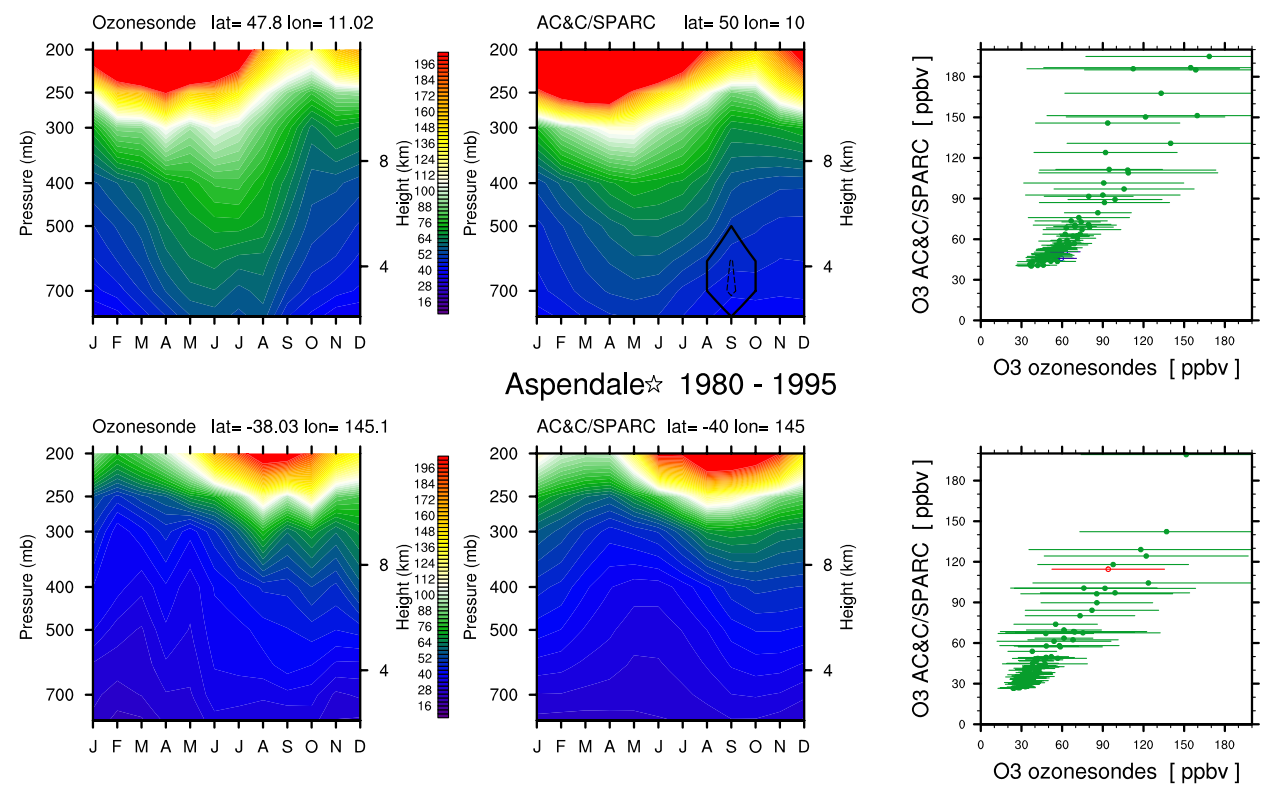

Fig. 11. Comparison of tropospheric ozone (ppb) from the AC\&C/SPARC ozone database with ozonesonde observations at three different sites. The first column shows the annual cycle in observations from Logan et al. (1999), the second column is the equivalent plot from the AC\&C/SPARC ozone database. The final column compares all points, with bars indicating the standard deviation in the observations. Where the model overpredicts (underpredicts) observations by more than one standard deviation, the point is plotted in red (purple); these points are shown in the second column by the solid (dashed) contours.

the overlying stratosphere, where ozone levels are projected to rise.

\section{Radiative forcing}

\subsection{Radiative forcing code and methods}

We used the Edwards and Slingo (1996) code to calculate ozone radiative forcings. This code solves the two-stream (i.e. upwards and downwards) fluxes of radiation in both the short-wave (SW, i.e. solar) and long-wave (LW, i.e. terrestrial) regions of the spectrum. Spectral resolution can be varied: here a low spectral resolution is used, with $8 \mathrm{LW}$ bands and $6 \mathrm{SW}$ bands. This resolution is typical of GCMs, and gives good agreement with much higher resolution versions of the code, across a range of conditions (Edwards and Slingo, 1996). In the $\mathrm{SW}$, absorption by $\mathrm{H}_{2} \mathrm{O}, \mathrm{CO}_{2}, \mathrm{O}_{3}, \mathrm{O}_{2}$ and aerosols is included. In the $\mathrm{LW}$, absorption and emission by $\mathrm{H}_{2} \mathrm{O}, \mathrm{CO}_{2}, \mathrm{~N}_{2} \mathrm{O}, \mathrm{CH}_{4}, \mathrm{O}_{3}, \mathrm{CFC} 11, \mathrm{CFC} 12$ and aerosol is included. Data from the HITRAN92 molecular database (Rothman et al., 1992), together with LOWTRAN7 (Kneizys et al., 1988) for $\mathrm{O}_{3}$ in the $\mathrm{SW}$ are used. Line and continuum absorption are treated as in (Clough et al., 1989). The effects of clouds are included in the calculations performed here. Recent updates to ozone absorption coefficients in the code (J. Manners, personal communication, 2011) have not been included in the results presented here, and preliminary results suggest that this is an important caveat, as the updates have some impact on calculated ozone radiative forcings.

To calculate an ozone radiative forcing, the code is applied as follows. A base calculation of radiation fluxes is performed (using decadally averaged monthly ozone data from the 1850s) for each column of model atmosphere (i.e. for each $5^{\circ} \times 5^{\circ}$ grid square, every month). Profiles of several 

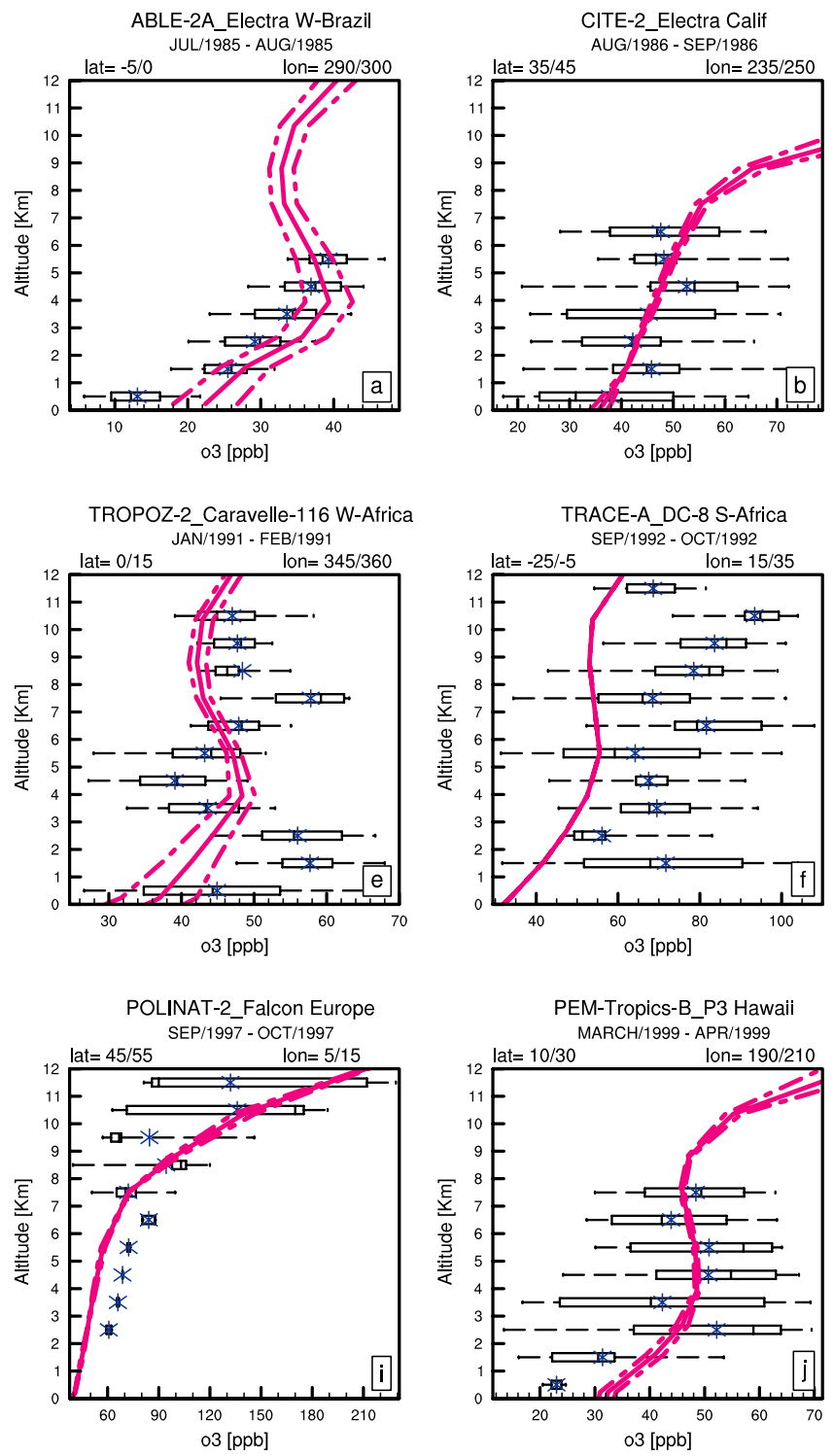
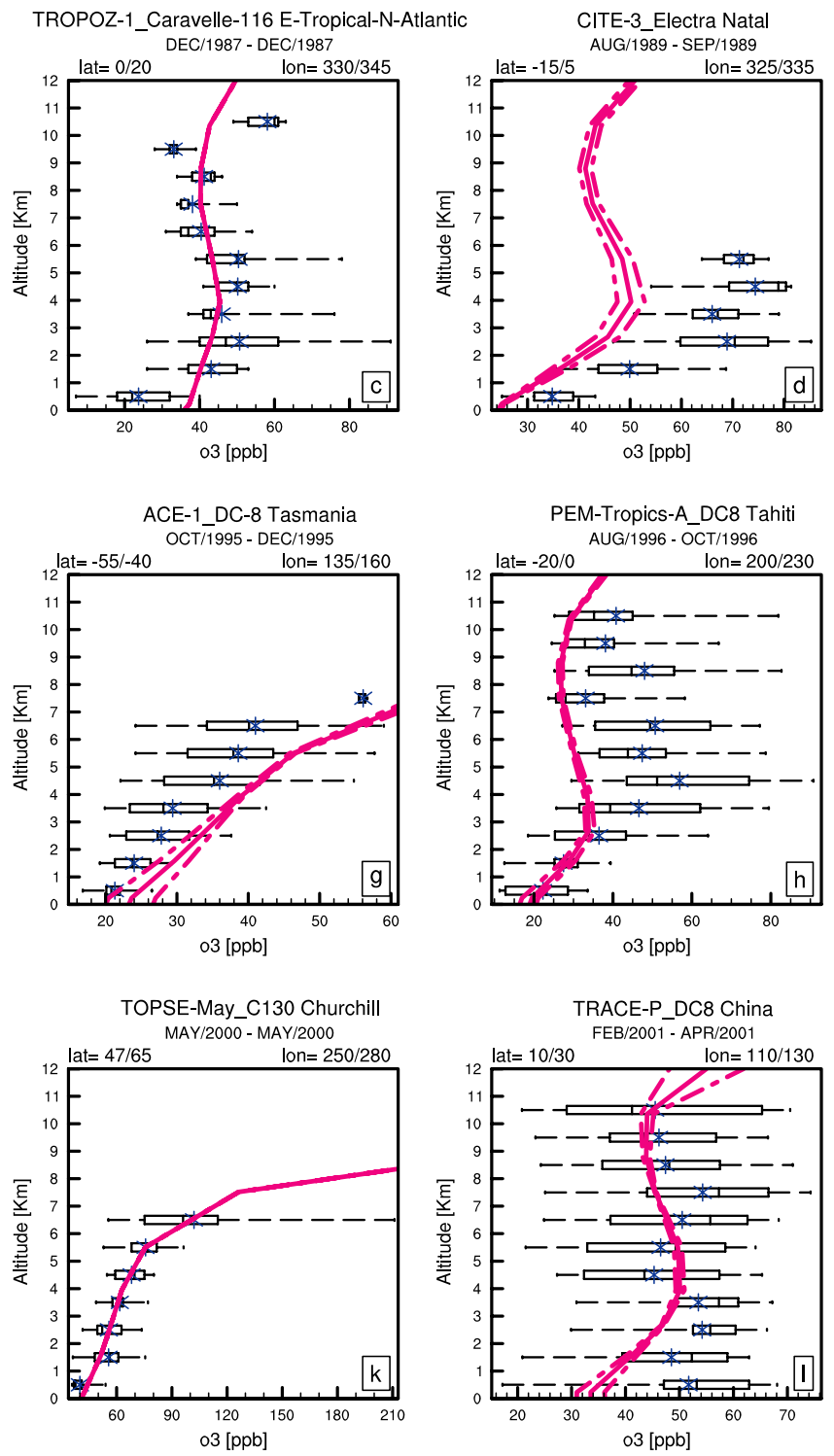

Fig. 12. Vertical profiles of campaign observation from Emmons et al. (2000) and the AC\&C/SPARC ozone database for different regions. Boxes and whiskers indicate the central $50 \%$ and $90 \%$ of the observations, with a vertical bar at the median and a star in the mean. The AC\&C/SPARC ozone database is averaged over the same latitudes as the observations. Mean and standard deviations over the same time period of the campaign are shown by the solid and dashed lines.

atmospheric and surface properties (e.g. temperature, humidity, clouds, surface albedo) are required; here we use model data from an integration of the 64 level HadAM3 GCM (Pope et al., 2000; Tian et al., 2005). The radiation calculation is then repeated, keeping everything the same, but using a different ozone field (e.g. from the 2000s). The change in net radiation at the tropopause between these two calculations gives the instantaneous radiative forcing.

By changing the ozone field, heating rates in the stratosphere will have changed. If such a change were to happen in the real atmosphere, stratospheric temperatures would re- spond quickly (days to months) - much more quickly than the surface-troposphere system, which will respond on multiannual timescales. A better estimate of the long-term forcing on the surface climate takes into account this short-term response of stratospheric temperatures (Forster et al., 2007). Stratospheric temperature adjustment was achieved by first calculating stratospheric heating rates for the base atmosphere. The stratosphere was assumed to be in thermal equilibrium, with dynamical heating exactly balancing the radiative heating. Furthermore, the dynamics were assumed to remain constant following a perturbation to ozone. Hence 
(a) Percentage changes in profile ozone at $80 \mathrm{~S}$
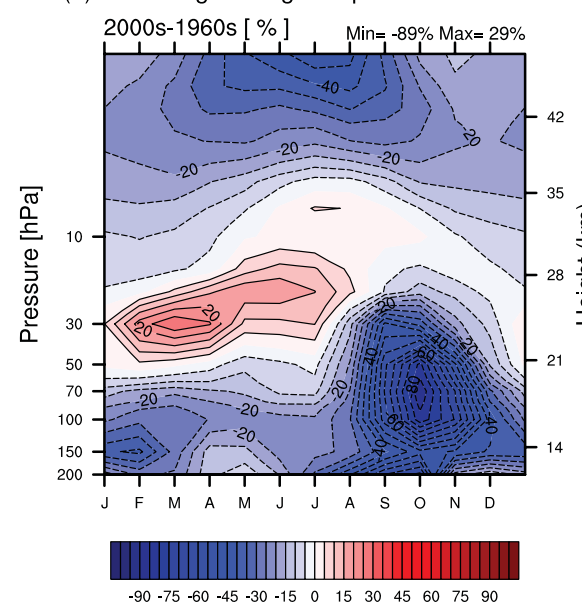

(c) Percentage changes in profile ozone at $80 \mathrm{~S}$

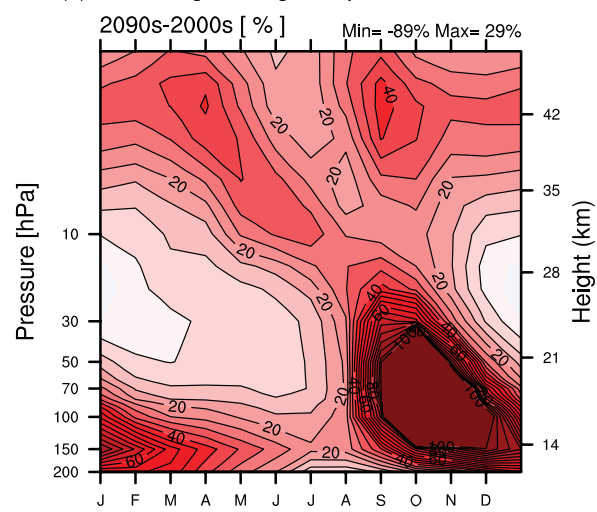

(b) Percentage changes in meridional cross section

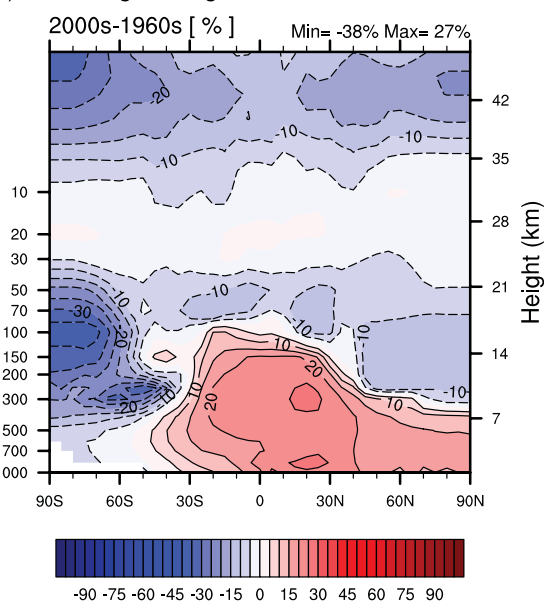

(d) Percentage changes in meridional cross section

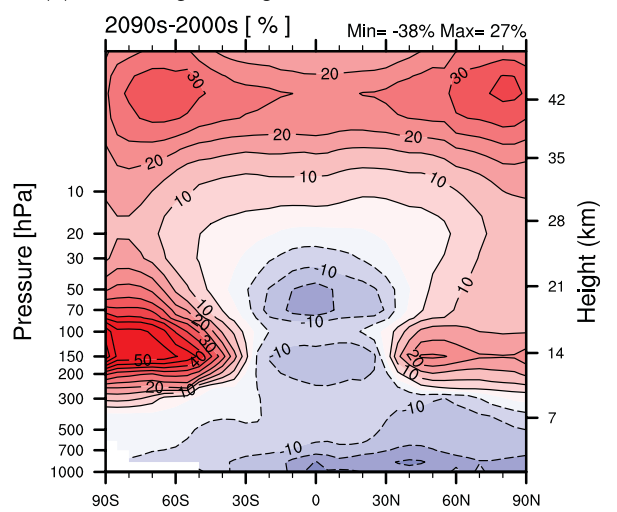

Fig. 13. (a) Annual cycle at $80^{\circ} \mathrm{S}$ and (b) meridional cross-section of the percentage differences in ozone between the 1960s and the 2000s. (c, d) Same as (a, b), but for the differences between the 2000s and the 2090s. The future GHG scenario shown is RCP 4.5 in the troposphere and SRES A1B in the stratosphere.

to maintain equilibrium, radiative heating rates must also remain unchanged. To achieve this, stratospheric temperatures were iteratively adjusted in the perturbed case, until stratospheric radiative heating rates returned to their base values. This procedure is called the fixed dynamical heating approximation (Ramanathan and Dickinson, 1979).

Here we report global annual mean forcings at the tropopause, after stratospheric temperature adjustment, taking an area weighted average over all months. The code has previously been used to calculate tropospheric ozone radiative forcings (Stevenson et al., 1998, 2000, 2006). These previous studies have used 19 vertical levels, with the levels concentrated towards the surface. The 19-level version was upgraded to 64 levels, providing much more vertical resolution in the stratosphere and upper troposphere.

In order to separate the radiative forcing components from changes in tropospheric and stratospheric ozone, one set of calculations was performed with changes in ozone only above the tropopause, and another where ozone only changed in the troposphere. We use essentially the same climatological definition of the tropopause as used earlier in the construction of the ozone database. We do not use exactly the same tropopause because the data is interpolated to a different vertical grid from that in the database in order to perform the radiation calculations. This means that close to the tropopause, the interpolation mixes some values from the stratospheric and tropospheric parts of the database. We chose to keep the stratospheric RF calculations purely stratospheric, so all values following interpolation that included any influence of tropospheric values were included in the tropospheric RF calculation. This means the tropospheric RFs include a small component (less than $0.01 \mathrm{~W} \mathrm{~m}^{-2}$ ) from the stratosphere. Calculations were also performed with ozone changing throughout the whole atmosphere - results showed that summing tropospheric and stratospheric radiative forcings gave the same result (within 1-2\%) as the whole atmosphere calculation, indicating that non-linear effects were negligible. 


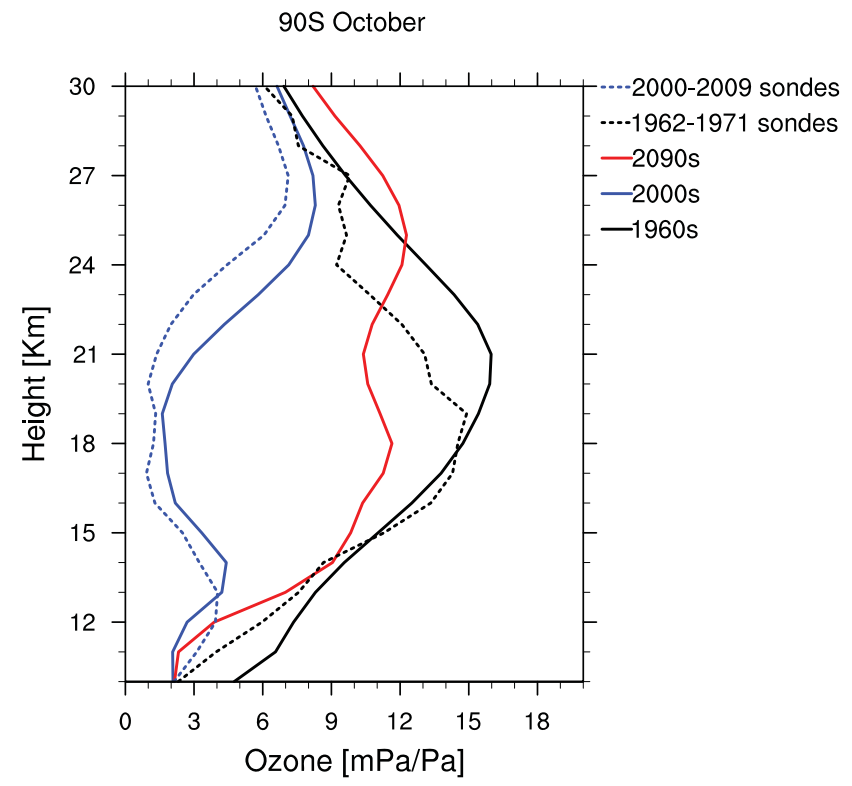

Fig. 14. October mean vertical ozone profiles from the AC\&C/SPARC ozone database over the South Pole for the 1960s, 2000s and 2090s (black, blue, and red solid lines, respectively) compared to ozonesondes for the 1960s (1962-1971, black dashed line) and the recent past (2000-2009, blue dashed line). The future GHG scenario shown is RCP 4.5 in the troposphere and SRES A1B in the stratosphere.

\subsection{Radiative forcing results}

Figure 15a shows a map of the tropospheric $\mathrm{O}_{3}$ radiative forcing (RF) for the period from the 1850 s to the 2000s (global mean: $0.229 \mathrm{~W} \mathrm{~m}^{-2}$; cf. 0.35 (range 0.25 $0.65) \mathrm{W} \mathrm{m}^{-2}$ from Forster et al., 2007). The lower value compared to most previous estimates is mainly due to the smaller change in ozone in this study, although the details of the radiation calculations, such as the treatment of clouds (see below), may also be important. The RF peaks at over $750 \mathrm{~mW} \mathrm{~m}^{-2}$ over the Middle East, and is positive everywhere except over the Southern Ocean and Antarctica, where the RF is negative. Figure $15 \mathrm{~b}$ shows a map of the stratospheric $\mathrm{O}_{3} \mathrm{RF}$ for the period from the 1850 s to the $2000 \mathrm{~s}$ (global mean: $-0.078 \mathrm{~W} \mathrm{~m}^{-2}$; cf. $-0.05 \pm 0.1 \mathrm{~W} \mathrm{~m}^{-2}$ : Forster et al., 2007). The negative forcing is strongest at high latitudes, especially the Antarctic, and is due to ozone depletion caused by anthropogenic halogen loading.

Table 5 shows the SW and LW components of the RFs (cf. Gauss et al. (2006): Tables 5 and 6). About two thirds of the tropospheric ozone RF is in the LW, and one third in the SW. The LW forcing peaks where large ozone changes coincide with a large temperature contrast between the surface/lower atmosphere and the upper troposphere, whereas the SW forcing peaks where the ozone changes coincide with high albedos. The stratospheric ozone RF comprises a pos- itive SW component and a (larger in magnitude) negative LW component. A decrease in stratospheric ozone levels lets more downwelling SW into the troposphere, and since the upwelling SW flux must be less than the downwelling $\mathrm{SW}$, there must be a positive SW RF at the tropopause associated with stratospheric ozone depletion. The negative LW RF mainly arises due to the stratospheric temperature adjustment (i.e. stratospheric cooling, due to the decrease in stratospheric ozone). This reduces the downwelling LW flux at the tropopause; the upwelling LW at the tropopause is unchanged, since tropospheric temperatures are fixed, hence the negative LW RF.

The treatment of clouds in the radiation code has a significant influence on the calculated RFs (Table 5), and contributes uncertainty to the values. With clouds completely removed from the calculations, the global mean tropospheric ozone RF is $38 \%$ higher. The SW RF component is slightly smaller when clouds are removed, as the albedo is reduced, and this outweighs the effect of more SW radiation reaching the surface, which allows $\mathrm{O}_{3}$ changes below clouds to exert a larger RF. The clear-sky LW RF is much larger, as the removal of clouds exposes the hotter surface, the main source of upwelling LW radiation; this allows more upwelling LW radiation to pass through the parts of the atmosphere with higher levels of ozone. Removing clouds has only a small influence on the net stratospheric ozone RF, although the influences on the SW and LW components are both increased in magnitude (Table 5). The SW stratospheric $\mathrm{O}_{3} \mathrm{RF}$ increases when clouds are removed, due to the reduced albedo (the downwelling SW is unchanged by the removal of clouds, but the upwelling SW is reduced, hence the net stratospheric $\mathrm{O}_{3} \mathrm{SW} R F$ at the tropopause is increased). The LW forcing becomes more negative when clouds are removed because the upwelling LW is increased, but the downwelling LW (controlled by the temperature of the overlying stratosphere) is largely unchanged. We use cloud fields (cloud fractions, cloud liquid water, and cloud ice) from the HadAM3 model; these particular cloud fields have not been compared in detail to observations, although the model in general is known to produce a reasonable climate (Pope et al., 2000). It should be noted that a climate model that is forced with the AC\&C/SPARC ozone database will produce a slightly different RF for a variety of reasons, e.g. different clouds, tropopause and concentrations of other radiatively active species.

Figure 16a- $d$ shows the evolution of zonally averaged tropospheric ozone RF from the 1850s up to the 2090s, for the four RCP emissions scenarios (the plots are identical up to the 2000s). The negative RFs at high southern latitudes have emerged since the 1960s, and are associated with decreases in tropospheric ozone, largely driven by downwards transport of air with depleted stratospheric ozone levels. The global mean tropospheric ozone RF grew approximately exponentially up to the 1970s, when growth started to flatten off (Fig. 15). The future tropospheric ozone RFs retain a similar 

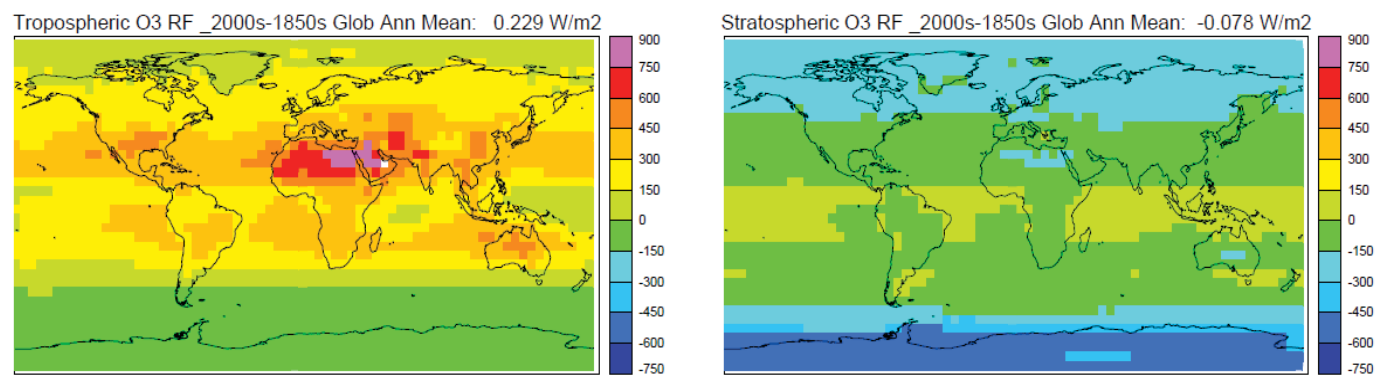

Fig. 15. Ozone radiative forcings $\left(\mathrm{mW} \mathrm{m}^{-2}\right)$ at the tropopause (after stratospheric temperature adjustment) for the 2000s, relative to the 1850s, for (a) tropospheric ozone and (b) stratospheric ozone.

Table 5. Global mean tropospheric (Trop) and stratospheric (Strat) ozone radiative forcings $\left(\mathrm{W} \mathrm{m}^{-2}\right.$, at the tropopause, after allowing for stratospheric temperature adjustment following the fixed dynamical heating approximation) for the 2000s relative to the $1850 \mathrm{~s}$, split into short-wave (SW) and long-wave (LW) components, for cloudy and clear skies.

\begin{tabular}{lrrr}
\hline & SW & LW & Total \\
\hline Trop cloudy & 0.084 & 0.146 & 0.229 \\
Trop clear & 0.081 & 0.236 & 0.317 \\
Strat cloudy & 0.122 & -0.200 & -0.078 \\
Strat clear & 0.163 & -0.238 & -0.075 \\
\hline
\end{tabular}

geographical distribution to the historical forcing, with peaks in the sub-tropics. Under the high RCP 8.5 emissions scenario, the global RF rises steadily, reaching $0.413 \mathrm{~W} \mathrm{~m}^{-2}$ by the 2090s. For RCP 6.0, the RF peaks at $0.235 \mathrm{~W} \mathrm{~m}^{-2}$ in the $2050 \mathrm{~s}$, before falling to $0.177 \mathrm{~W} \mathrm{~m}^{-2}$ by the 2090s. RCP 4.5 follows a similar trajectory, peaking at $0.255 \mathrm{~W} \mathrm{~m}^{-2}$ in the $2040 \mathrm{~s}$, before falling to $0.165 \mathrm{~W} \mathrm{~m}^{-2}$ by the $2090 \mathrm{~s}$. In the RCP 2.6 scenario, the RF peaks at $0.235 \mathrm{~W} \mathrm{~m}^{-2}$ in the 2010 s, then falls steadily to a value of $0.087 \mathrm{~W} \mathrm{~m}^{-2}$ by the 2090s.

The stratospheric ozone RF grew from near zero in the 1960s; the forcing from the 1850 s to the 1960s was insignificant (Fig. 15). The forcing grew rapidly through the 1970s and $1980 \mathrm{~s}$ before peaking in the $1990 \mathrm{~s}\left(-0.079 \mathrm{~W} \mathrm{~m}^{-2}\right)$, but has changed little since then up to present-day (2010) (Figs. 16e and 17). The magnitude of this value is considerably higher than that of the central stratospheric ozone RF reported by the $\mathrm{AR} 4$, which was $-0.05 \pm 0.1 \mathrm{~W} \mathrm{~m}^{-2}$ (Forster et al., 2007), although lies well within the stated uncertainties. The AR4 central value was based on observed changes in stratospheric ozone from 1979-1998; to allow for possible stratospheric ozone changes prior to 1979, the AR4 increased the uncertainty range but did not change the central value, implicitly assuming that there were no changes in stratospheric ozone prior to 1979. Simple linear interpolation of our decadal mean values suggests that for the period 19791998, we find the stratospheric ozone RF to increase in magnitude by $0.046 \mathrm{~W} \mathrm{~m}^{-2}$, which is quite consistent with the AR4 observationally based value. However, the regression model used here to extrapolate stratospheric ozone prior to 1979 predicts that there was pre-1979 ozone depletion in line with the elevated values of EESC in 1979. This assumption is supported by the CCMVal CCMs which clearly show significant pre-1979 ozone depletion proportional to the growth in EESC (Shepherd, 2008; Eyring et al., 2010a). As a result, our calculated stratospheric ozone RF, which is relative to pre-industrial times, is about $60 \%$ higher than the central value reported by the AR4.

The projections are based on a single future halogen loading scenario (see Sect. 3). Stratospheric ozone RF shows a gradual recovery at the poles to near pre-ozone depletion levels by the 2060s (Fig. 16e). However, at the same time as polar ozone recovers, tropical stratospheric ozone steadily decreases through the 21 st century, most strongly in the NH. These two effects approximately cancel themselves out in terms of global mean RF, which remains negative in the future, with a slight decrease in magnitude to about $-0.05 \mathrm{~W} \mathrm{~m}^{-2}$ in the mid 21 st century, then a slight increase in magnitude by the 2090s, with the stratospheric ozone RF moving from the poles to the tropics (Figs. 16e and 17). This near-cancellation of future RF changes in the global mean may be slightly overestimated, since as noted in Sect. 2.3 the merging of observed and modeled stratospheric ozone results in a non-recovery of lower stratospheric ozone in northern midlatitudes (see Figs. 2 and 3), which is inconsistent with the CCMVal model results (Austin et al., 2010).

\section{Summary}

This paper discussed the ozone database that has been released to the climate community in support of CMIP5 simulations in netCDF Climate and Forecast (CF) Metadata Convention at the PCMDI CMIP5 website (http://cmip-pcmdi. llnl.gov/). It covers the period 1850 to 2100 and can be used 

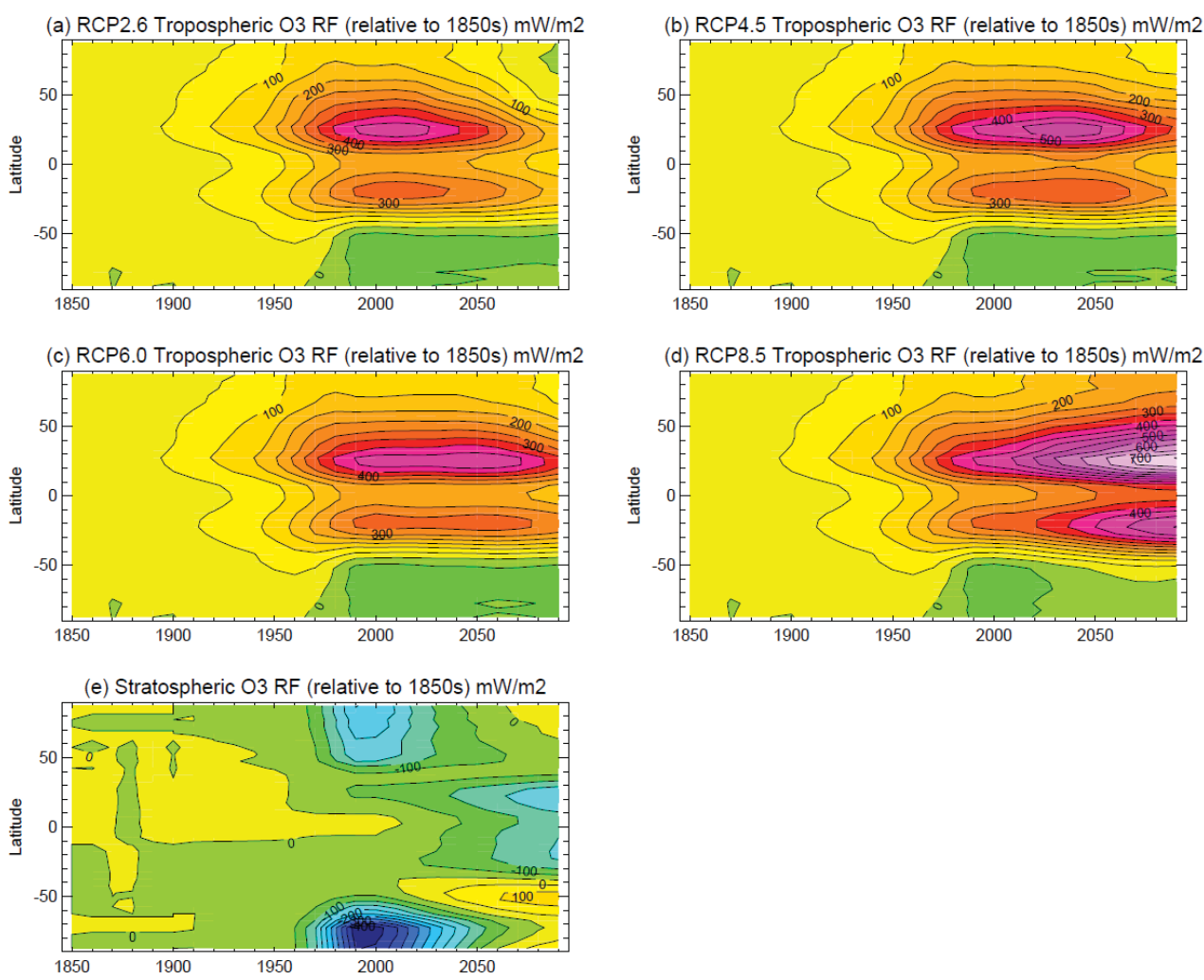

Fig. 16. Zonal mean radiative forcing, 1850s to the 2090s, (a-d) tropospheric ozone for four future scenarios (RCP2.6, RCP4.5, RCP6.0 and RCP8.5); and (e) stratospheric ozone (single scenario).

as forcing in general circulation or Earth system models that do not include interactive chemistry.

The historical part of the ozone database covers the period 1850 to 2009 and consists of separate stratospheric and tropospheric data sources. A multiple linear regression analysis of SAGE I+II satellite observations and polar ozonesonde measurements was used for the stratospheric dataset during the well-observed period from 1979 to 2005 . The regression includes terms representing equivalent effective stratospheric chlorine (EESC) and the 11-yr solar cycle variability. The EESC regression coefficients are used to extrapolate that data back in time, and form a stratospheric ozone time series backward to cover the entire historical time period 1850 2009. Three-dimensional (latitude, longitude, height) tropospheric data are derived from the chemistry-climate models CAM3.5 and GISS-PUCCINI. Both models simulate tropospheric and stratospheric chemistry with feedback to the radiation and were driven by the available historical (1850-2000) emissions described in Lamarque et al. (2010a).

The future part of the ozone database covers the period 2010 to 2100 and seamlessly extends the historical database. The future ozone timeseries also combines separate stratospheric and tropospheric data sources: the stratospheric ozone projections are taken from the future reference simulations (REF-B2) of the $13 \mathrm{CCMs}$ that performed a future

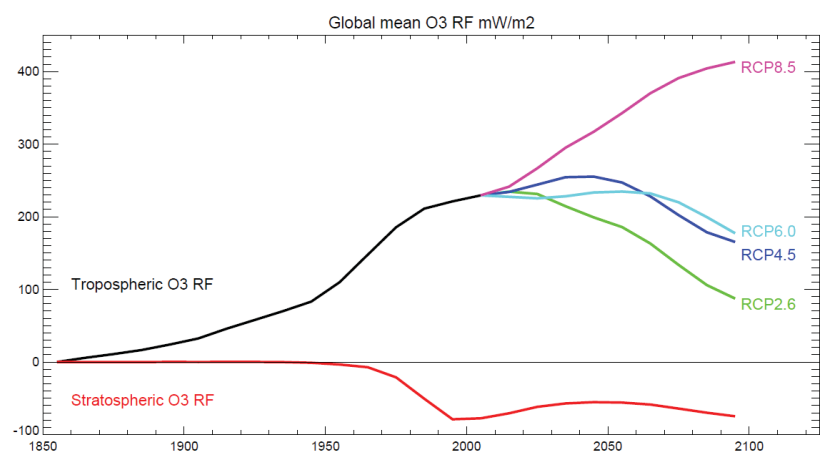

Fig. 17. Evolution (1850-2100) of decadal mean global average ozone radiative forcing, shown for tropospheric ozone (black up to 2000s) and stratospheric ozone (red). Beyond the 2000s, four different scenarios for tropospheric ozone precursor emissions are followed: RCP 2.6 (green), RCP 4.5 (blue), RCP 6.0 (cyan) and RCP 8.5 (magenta). The stratosphere follows a single scenario: the A1 adjusted halogen loading scenario, and is the average of results from $13 \mathrm{CCMs}$ that performed the REF-B2 scenario of CCMVal-2 (this follows the SRES A1B climate scenario). 
simulation until 2100 under the SRES A1b GHG scenario and the A1 adjusted halogen scenario in CCMVal-2. In the stratosphere, the multi-model mean of the REF-B2 simulations is used in all RCP scenarios. As in the past, stratospheric ozone data are zonal means rather than a full threedimensional field as in the troposphere. Unlike in the historical segment of the database (1850-2009), the REF-B2 simulations do not include the solar cycle. The ozone database here is therefore provided without solar cycle in the future, since climate model groups might want to use a future solar irradiance that is consistent with the one used in the climate model simulations for a regression. A regression of the solar signal similar to that in the historical part can be applied in case the representation of the solar forcing in the future ozone database should be maintained. Extended datasets with an extrapolation of the data to $0.01 \mathrm{hPa}$ for the use in high top models and datasets with the solar cycle added in the future have been constructed by the UK National Centre for Atmospheric Science (NCAS) and the UK MetOffice, respectively, and are available on the PCMDI website. The future tropospheric ozone time series continues the historical CAM3.5 simulation until 2100 using the four different Representative Concentration Pathways (RCPs). The stratospheric and tropospheric data are combined by simply merging the two data sets across the climatological tropopause, to produce a smooth final data set.

The stratospheric ozone database has been compared to a 20-yr (1980-1999) climatology of satellite measurements. The percentage differences between the climatological annual cycle from satellite data and the AC\&C/SPARC ozone database are less than $7 \%$ everywhere except over Antarctica in spring where the database underestimates the depth of the ozone hole. Tropospheric column ozone has been compared to a 6-yr (2005-2009) climatology from MLS/OMI satellite measurements. The geographical distribution and the annual cycle are well reproduced by the ozone database, but tropospheric column ozone is generally slightly lower than observed especially in the Southern Hemisphere. Tropospheric ozone mixing ratios have been evaluated with mean climatologies from ozonesondes (Logan et al., 1999) and in situ measurements from aircraft campaigns (Emmons et al., 2000). The vertical profiles of tropospheric ozone are broadly consistent with ozonesondes and in-situ measurements, with some deviations in regions of biomass burning.

We calculate that increases in tropospheric ozone from the 1850 s to the 2000 s produce a radiative forcing of $0.229 \mathrm{~W} \mathrm{~m}^{-2}$ (Fig. 16a), at the lower end of the IPCC range of $0.25-0.65 \mathrm{~W} \mathrm{~m}^{-2}$ (Forster et al., 2007). This probably reflects relatively small changes in biomass burning emissions since pre-industrial times in this study compared to most earlier work (Lamarque et al., 2010a), and also a larger impact of stratospheric ozone depletion filtering down into the troposphere at high southern latitudes. It may also be partly due to a different treatment of clouds, which have a relatively large influence on the calculated RF value (Ta- ble 5). The tropospheric ozone RF is concentrated in the sub-tropics, and grew exponentially up to the 1970s, before flattening off (Figs. 16 and 17). In the future scenarios, the tropospheric forcing increases to $\sim 0.4 \mathrm{~W} \mathrm{~m}^{-2}$ (RCP8.5), remains fairly steady before declining to $\sim 0.2 \mathrm{~W} \mathrm{~m}^{-2}$ (RCP6.0 and 4.5), and decreases steadily to $\sim 0.1 \mathrm{~W} \mathrm{~m}^{-2}$ (RCP2.6); these changes are mainly driven by the underlying $\mathrm{CH}_{4}$ concentrations in these scenarios. Decreases in stratospheric ozone, mainly at high latitudes, produced a RF from the 1850 s to the 2000s of $-0.08 \mathrm{~W} \mathrm{~m}^{-2}$ (Fig. 15b), somewhat more negative than the central AR4 value of $-0.05 \mathrm{~W} \mathrm{~m}^{-2}$, but within the stated AR4 range of -0.15 to $+0.05 \mathrm{~W} \mathrm{~m}^{-2}$ (Forster et al., 2007). Most of this forcing arose between the 1970s and the 1990s, and the larger magnitude found here results from stratospheric ozone decreases prior to 1979, which were assumed to be zero by the AR4. Over the time period 1979-1998, the stratospheric ozone RF calculated here changed from -0.033 to $-0.079 \mathrm{~W} \mathrm{~m}^{-2}$, a change that is very consistent with the AR4 observationally based estimate of $-0.05 \pm 0.05 \mathrm{~W} \mathrm{~m}^{-2}$ over this same period. However, the EESC-based regression model used here assumes that ozone depletion occurred prior to 1979 in line with the growth of EESC, an assumption that is well supported by the CCMVal CCMs (Eyring et al., 2010a). A negative stratospheric ozone RF of similar magnitude persists into the future, although its location shifts from high latitudes to the tropics. This shift is due to recovery of polar stratospheric ozone together with a decrease of tropical lower stratospheric ozone induced by a strengthened Brewer-Dobson circulation, although the extent of persistence of the negative RF is likely slightly overestimated here because of the lack of ozone recovery in the northern midlatitude stratosphere in the merged data set. The RF values given here are only indicative of the $\mathrm{RF}$ that will be produced in a climate model that is forced with the AC\&C/SPARC ozone database, since the climate model, for example, will not have exactly the same cloud distribution and tropopause. The different tropopause will matter if the ozone database is prescribed as absolute values and not relative to the tropopause.

We note that the most accurate option of representing ozone in climate model simulations is to calculate ozone interactively, so that changes in ozone feed back on atmospheric dynamics and radiation and vice versa. Compared with CMIP3 simulations, CCMVal-2 simulations - which in contrast to the CMIP3 simulations have interactive chemistry - have a mean stratospheric climate and variability that is much closer to the observations, based on pointwise comparisons of zonal-mean winds and temperature (Chapter 10 of SPARC CCMVal, 2010). In the troposphere, mean climate and synoptic variability are similarly close to the observations in both groups of simulations, while interannual variability tends to be better simulated by the CCMVal models. Therefore, a prescribed ozone field is always a compromise since the ozone field, for example, will not be consistent with the meteorological state of the climate model in a particular 
year. However, compared to the CMIP3 models that were used in IPCC (2007) where around half of the models prescribed climatological mean ozone rather than time varying ozone (see Son et al. (2008) for details), prescribing ozone as a time varying field as presented in this ozone database rather than a climatology is a large improvement from CMIP3 to CMIP5. The expected recovery of stratospheric ozone will be significantly affected by climate change, which is important for radiative forcing. As has been shown here, while the global mean stratospheric ozone radiative forcing remains similar, the geographical pattern moves from the poles to the tropics during the 21 st century. In addition, the impact of the ozone hole on high latitude surface climate has been substantial, so the impact of ozone recovery in the future will also be important. This has potential implications for southern high-latitude climate (e.g. tropopause height, jet location, Hadley Cell extent, carbon uptake, and sea-ice melt). A deceleration of the poleward side of the jet (a decrease in the Southern Annular Mode) is found in stratosphere-resolving CCM simulations due to the decline of the ozone hole in the first half of the 21st Century (e.g. Perlwitz et al., 2008; Son et al., 2008). This is opposite to the response found in the mean of the IPCC AR4, but can be captured in CMIP3 models with prescribed time varying ozone (Son et al., 2010).

\section{Supplementary material related to this article is available online at: http://www.atmos-chem-phys.net/11/11267/2011/ acp-11-11267-2011-supplement.zip.}

Acknowledgements. We acknowledge the Chemistry-Climate Model Validation (CCMVal) Activity for WCRP's (World Climate Research Programme) SPARC (Stratospheric Processes and their Role in Climate) project for organizing and coordinating the stratospheric model data analysis activity. We particularly thank John Austin (AMTRAC3, NOAA GFDL, USA), Hideharu Akiyoshi, Yousuke Yamashita and Tetsu Nakamura (CCSRNIES, NIES, Tokyo, Japan), David Plummer and John Scinocca (CMAM, Environment Canada, Canada), Martine Michou and Hubert Teyssedre (CNRM-ACM, Meteo-France, France), Steven Pawson and Rich Stolarski (GEOSCCM, NASA/GSFC, USA), Slimane Bekki and Marion Marchand (LMDZrepro, IPSL, France), Kiyotaka Shibata (MRI, MRI, Japan), Eugene Rozanov and Thomas Peter (SOCOL, PMOD/WRC and ETHZ, Switzerland), Eva Mancini and Giovanni Pitari (ULAQ, University of L'Aquila, Italy), Martyn Chipperfield, Sandip Dhomse and Wenshou Tian (UMSLIMCAT, University of Leeds, UK), Peter Braesicke, Olaf Morgenstern, and John Pyle (UMUKCAUCAM, University of Cambridge, UK), and Doug Kinnison, Andrew Gettelman, and Rolando Garcia (WACCM, NCAR, USA) for providing their results for the multi-model mean stratospheric ozone projections.

Edited by: A. J. G. Baumgaertner

\section{References}

Akiyoshi, H., Zhou, L. B., Yamashita, Y., Sakamoto, K., Yoshiki, M., Nagashima, T., Takahashi, M., Kurokawa, J., Takigawa, M., and Imamura, T.: A CCM simulation of the breakup of the Antarctic polar vortex in the years 1980\&\#8211;2004 under the CCMVal scenarios, J. Geophys. Res., 114, D03103, doi:10.1029/2007jd009261, 2009.

Austin, J., Wilson, R. J., Akiyoshi, H., Bekki, S., Butchart, N., Claud, C., Fomichev, V. I., Forster, P., Garcia, R. R., Gillett, N. P., Keckhut, P., Langematz, U., Manzini, E., Nagashima, T., Randel, W. J., Rozanov, E., Shibata, K., Shine, K. P., Struthers, H., Thompson, D. W. J., Wu, F., and Yoden, S.: Coupled chemistry climate model simulations of stratospheric temperatures and their trends for the recent past, Geophys. Res. Lett., 36, L13809, doi:10.1029/2009g1038462, 2009.

Austin, J., Scinocca, J., Plummer, D., Oman, L., Waugh, D., Akiyoshi, H., Bekki, S., Braesicke, P., Butchart, N., Chipperfield, M., Cugnet, D., Dameris, M., Dhomse, S., Eyring, V., Frith, S., Garcia, R. R., Garny, H., Gettelman, A., Hardiman, S. C., Kinnison, D., Lamarque, J. F., Mancini, E., Marchand, M., Michou, M., Morgenstern, O., Nakamura, T., Pawson, S., Pitari, G., Pyle, J., Rozanov, E., Shepherd, T. G., Shibata, K., Teyssèdre, H., Wilson, R. J., and Yamashita, Y.: Decline and recovery of total column ozone using a multimodel time series analysis, J. Geophys. Res., 115, D00M10, doi:10.1029/2010jd013857, 2010.

Bodeker, G. E., Shiona, H., and Eskes, H.: Indicators of Antarctic ozone depletion, Atmos. Chem. Phys., 5, 2603-2615, doi:10.5194/acp-5-2603-2005, 2005.

Butchart, N., Scaife, A., Bourqui, M., de Grandpré, J., Hare, S., Kettleborough, J., Langematz, U., Manzini, E., Sassi, F., Shibata, K., Shindell, D., and Sigmond, M.: Simulations of anthropogenic change in the strength of the Brewer-Dobson circulation, Clim. Dynam., 27, 727-741, doi:10.1007/s00382-006-0162-4, 2006.

Clarke, L., Edmonds, J., Jacoby, H., Pitcher, H., Reilly, J., and Richels, R.: Scenarios of Greenhouse Gas Emissions and Atmospheric Concentrations, Department of Energy, Office of Biological \& Environmental Research, Washington, 7 DC, USA, 154 pp., 2007.

Clough, S. A., Kneizys, F. X., and Davies, R. W.: Line shape and the water vapor continuum, Atmos. Res., 23, 229-241, doi:10.1016/0169-8095(89)90020-3, 1989.

Cofala, J., Amann, M., Heyes, C., Klimont, Z., Posch, M., Schöpp, W., Tarasson, L., Jonson, J., Whall, C., and Stavrakaki, A.: Final Report: Analysis of Policy Measures to Reduce Ship in 10 the Context of the Revision of the National Emissions Ceilings Directive, 2007.

Collins, W. J., Derwent, R. G., Garnier, B., Johnson, C. E., Sanderson, M. G., and Stevenson, D. S.: Effect of stratospheretroposphere exchange on the future tropospheric ozone trend, J. Geophys. Res., 108, 8528, doi:10.1029/2002jd002617, 2003.

de Grandpré, J., Beagley, S. R., Fomichev, V. I., Griffioen, E., McConnell, J. C., Medvedev, A. S., and Shepherd, T. G.: Ozone climatology using interactive chemistry: Results from the Canadian Middle Atmosphere Model, J. Geophys. Res., 105, 2647526491, doi:10.1029/2000jd900427, 2000.

de Laat, A. T. J., Aben, I., and Roelofs, G. J.: A model perspective on total tropospheric $\mathrm{O}_{3}$ column variability and implications for satellite observations, J. Geophys. Res., 110, D13303, doi:10.1029/2004jd005264, 2005. 
Dentener, F., Stevenson, D., Cofala, J., Mechler, R., Amann, M., Bergamaschi, P., Raes, F., and Derwent, R.: The impact of air pollutant and methane emission controls on tropospheric ozone and radiative forcing: CTM calculations for the period 19902030, Atmos. Chem. Phys., 5, 1731-1755, doi:10.5194/acp-51731-2005, 2005.

Déqué, M.: Frequency of precipitation and temperature extremes over France in an anthropogenic scenario: Model results and statistical correction according to observed values, Global Planet. Change, 57, 16-26, doi:10.1016/j.gloplacha.2006.11.030, 2007.

Edwards, J. M. and Slingo, A.: Studies with a flexible new radiation code. I: Choosing a configuration for a largescale model, Q. J. Roy. Meteorol. Soc., 122, 689-719, doi:10.1002/qj.49712253107, 1996.

Egorova, T., Rozanov, E., Zubov, V., Manzini, E., Schmutz, W., and Peter, T.: Chemistry-climate model SOCOL: a validation of the present-day climatology, Atmos. Chem. Phys., 5, 1557-1576, doi:10.5194/acp-5-1557-2005, 2005.

Emmons, L. K., Hauglustaine, D. A., Müller, J.-F., Carroll, M. A., Brasseur, G. P., Brunner, D., Staehelin, J., Thouret, V., and Marenco, A.: Data composites of airborne observations of tropospheric ozone and its precursors, J. Geophys. Res., 105, 2049720538, doi:10.1029/2000jd900232, 2000.

Eyring, V.: Modelling of the coupled chemistry-climate system: projections of stratospheric ozone in the 21 st century and impact of shipping on atmospheric composition and climate, Deutsches Zentrum für Luft- und Raumfahrt, Köln, 56 pp., 2008.

Eyring, V., Butchart, N., Waugh, D. W., Akiyoshi, H., Austin, J., Bekki, S., Bodeker, G. E., Boville, B. A., Brühl, C., Chipperfield, M. P., Cordero, E., Dameris, M., Deushi, M., Fioletov, V. E., Frith, S. M., Garcia, R. R., Gettelman, A., Giorgetta, M. A., Grewe, V., Jourdain, L., Kinnison, D. E., Mancini, E., Manzini, E., Marchand, M., Marsh, D. R., Nagashima, T., Newman, P. A., Nielsen, J. E., Pawson, S., Pitari, G., Plummer, D. A., Rozanov, E., Schraner, M., Shepherd, T. G., Shibata, K., Stolarski, R. S., Struthers, H., Tian, W., and Yoshiki, M.: Assessment of temperature, trace species, and ozone in chemistry-climate model simulations of the recent past, J. Geophys. Res., 111, D22308, doi:10.1029/2006jd007327, 2006.

Eyring, V., Waugh, D. W., Bodeker, G. E., Cordero, E., Akiyoshi, H., Austin, J., Beagley, S. R., Boville, B. A., Braesicke, P., Brühl, C., Butchart, N., Chipperfield, M. P., Dameris, M., Deckert, R., Deushi, M., Frith, S. M., Garcia, R. R., Gettelman, A., Giorgetta, M. A., Kinnison, D. E., Mancini, E., Manzini, E., Marsh, D. R., Matthes, S., Nagashima, T., Newman, P. A., Nielsen, J. E., Pawson, S., Pitari, G., Plummer, D. A., Rozanov, E., Schraner, M., Scinocca, J. F., Semeniuk, K., Shepherd, T. G., Shibata, K., Steil, B., Stolarski, R. S., Tian, W., and Yoshiki, M.: Multimodel projections of stratospheric ozone in the 21st century, J. Geophys. Res., 112, D16303, doi:10.1029/2006jd008332, 2007.

Eyring, V., Cionni, I., Bodeker, G. E., Charlton-Perez, A. J., Kinnison, D. E., Scinocca, J. F., Waugh, D. W., Akiyoshi, H., Bekki, S., Chipperfield, M. P., Dameris, M., Dhomse, S., Frith, S. M., Garny, H., Gettelman, A., Kubin, A., Langematz, U., Mancini, E., Marchand, M., Nakamura, T., Oman, L. D., Pawson, S., Pitari, G., Plummer, D. A., Rozanov, E., Shepherd, T. G., Shibata, K., Tian, W., Braesicke, P., Hardiman, S. C., Lamarque, J. F., Morgenstern, O., Pyle, J. A., Smale, D., and Yamashita, Y.: Multi-model assessment of stratospheric ozone return dates and ozone recovery in CCMVal-2 models, Atmos. Chem. Phys., 10, 9451-9472, doi:10.5194/acp-10-9451-2010, 2010a.

Eyring, V., Cionni, I., Lamarque, J. F., Akiyoshi, H., Bodeker, G. E., Charlton-Perez, A. J., Frith, S. M., Gettelman, A., Kinnison, D. E., Nakamura, T., Oman, L. D., Pawson, S., and Yamashita, Y.: Sensitivity of 21 st century stratospheric ozone to greenhouse gas scenarios, Geophys. Res. Lett., 37, L16807, doi:10.1029/2010gl044443, 2010b.

Fiore, A. M., Jacob, D., Bey, I., Yantosca, R., Field, B., Fusco, A., and Wilkinson, J.: Background ozone over the United States in summer: origin,trend, and contribution to pollution episodes, J. Geophys. Res., 107, 4275, doi:10.1029/2001JD000982, 2002.

Fomichev, V. I., Jonsson, A. I., de Grandpré, J., Beagley, S. R., McLandress, C., Semeniuk, K., and Shepherd, T. G.: Response of the Middle Atmosphere to $\mathrm{CO} 2$ Doubling: Results from the Canadian Middle Atmosphere Model, J. Climate, 20, 11211144, doi:10.1175/JCLI4030.1, 2007.

Forster, P., Ramaswamy, V., Artaxo, P., Berntsen, T., Betts, R., Fahey, D. W., Haywood, J., Lean, J., Lowe, D. C., Myhre, G., Nganga, J., Prinn, R., Raga, G., Schulz, M., and Van Dorland, R.: Changes in Atmospheric Constituents and in Radiative Forcing, in: Climate Change 2007: The Physical Science Basis. Contribution of Working Group I to the Fourth Assessment Report of the Intergovernmental Panel on Climate Change, edited by: Solomon, S., D. Qin, M. Manning, Z. Chen, M. Marquis, K.B. Averyt, M.Tignor and H.L. Miller Cambridge University Press, Cambridge, United Kingdom and New York, NY, USA, 2007.

Fortuin, J. P. F. and Kelder, H.: An ozone climatology based on ozonesonde and satellite measurements, J. Geophys. Res., 103, 31709-31734, doi:10.1029/1998jd200008, 1998.

Fujino, J., Nair, R., Kainuma, M., Masui, T., and Matsuoka, Y.: Multi-gas Mitigation Analysis on Stabilization Scenarios Using Aim Global Model, The Energy Journal, Multi-Greenhouse Gas Mitigation and Climate Policy, 2006.

Garcia, R. R., Marsh, D. R., Kinnison, D. E., Boville, B. A., and Sassi, F.: Simulation of secular trends in the middle atmosphere, 1950-2003, J. Geophys. Res., 112, D09301, doi:10.1029/2006jd007485, 2007.

Gauss, M., Myhre, G., Isaksen, I. S. A., Grewe, V., Pitari, G., Wild, O., Collins, W. J., Dentener, F. J., Ellingsen, K., Gohar, L. K., Hauglustaine, D. A., Iachetti, D., Lamarque, F., Mancini, E., Mickley, L. J., Prather, M. J., Pyle, J. A., Sanderson, M. G., Shine, K. P., Stevenson, D. S., Sudo, K., Szopa, S., and Zeng, G.: Radiative forcing since preindustrial times due to ozone change in the troposphere and the lower stratosphere, Atmos. Chem. Phys., 6, 575-599, doi:10.5194/acp-6-575-2006, 2006.

Hassler, B., Bodeker, G. E., Cionni, I., and Dameris, M.: A vertically resolved, monthly mean, ozone database from 1979 to 2100 for constraining global climate model simulations, Int. J. Remote Sensing, 30, 4009-4018, doi:10.1080/01431160902821874, 2009.

Hauglustaine, D. A., Lathière, J., Szopa, S., and Folberth, G. A.: Future tropospheric ozone simulated with a climatechemistry-biosphere model, Geophys. Res. Lett., 32, L24807, doi:10.1029/2005g1024031, 2005.

Hegglin, M. I. and Shepherd, T. G.: Large climate-induced changes in ultraviolet index and stratosphere-to-troposphere ozone flux, Nature Geosci., 2, 687-691, 2009.

Hijioka, Y., Matsuoka, Y., Nishimoto, N., Masui, M., and 
Kainuma,M.: Global GHG emissions scenarios under GHG concentration stabilization targets, J. Global Environ. Eng., 13, 97108, 2008.

IPCC: Climate Change 2001 - The Scientific Basis: Contribution of Working Group I to the Third Assessment Report of the IPCC, edited by: Houghton, J. T., Ding, Y., Griggs, D. J., Noguer, M., van der Linden, P. J., Dai, X., Maskell, K., and Johnson, C. A., Cambridge University Press, 881 pp., 2001.

IPCC: Climate Change 2007 - The Physical Science Basis: Working Group I Contribution to the Fourth Assessment Report of the IPCC, edited by: Solomon, S., Qin, D., Manning, M., Chen, Z., Marquis, M., Averyt, K. B., Tignor, M., and Miller, H. L., Cambridge University Press, 2007.

Isaksen, I. S. A., Granier, C., Myhre, G., Berntsen, T. K., Dalsøren, S. B., Gauss, M., Klimont, Z., Benestad, R., Bousquet, P., Collins, W., Cox, T., Eyring, V., Fowler, D., Fuzzi, S., Jöckel, P., Laj, P., Lohmann, U., Maione, M., Monks, P., Prevot, A. S. H., Raes, F., Richter, A., Rognerud, B., Schulz, M., Shindell, D., Stevenson, D. S., Storelvmo, T., Wang, W. C., van Weele, M., Wild, M., and Wuebbles, D.: Atmospheric composition change: Climate-Chemistry interactions, Atmos. Environ., 43, 5138-5192, doi:10.1016/j.atmosenv.2009.08.003, 2009.

Jacob, D. J. and Winner, D. A.: Effect of climate change on air quality, Atmos. Environ., 43, 51-63, doi:10.1016/j.atmosenv.2008.09.051, 2009.

Johnson, C. E., Stevenson, D. S., Collins, W. J., and Derwent, R. G.: Role of climate feedback on methane and ozone studied with a Coupled Ocean-Atmosphere-Chemistry Model, Geophys. Res. Lett., 28, 1723-1726, doi:10.1029/2000g1011996, 2001.

Jourdain, L., Bekki, S., Lott, F., and Lefèvre, F.: The coupled chemistry-climate model LMDz-REPROBUS: description and evaluation of a transient simulation of the period 1980-1999, Ann. Geophys., 26, 1391-1413, doi:10.5194/angeo-26-13912008, 2008.

Kneizys, F. X., Shettle, E. P., Abreu, L. W., Chetwynd, J. H., Anderson, G. P., Gallery, W. O., Selby, J. E. A., and Clough, S. A.: Users Guide to LOWTRAN 7, NTIS AD A206773, edited by: AFGL-TR-88-0177, Air Force Geophysics Laboratory,Hanscom Air Force Base, Massachusetts, 1988.

Lamarque, J. F., Hess, P., Emmons, L., Buja, L., Washington, W., and Granier, C.: Tropospheric ozone evolution between 1890 and 1990, J. Geophys. Res., 110, D08304, doi:10.1029/2004jd005537, 2005.

Lamarque, J.-F., Kinnison, D. E., Hess, P. G., and Vitt, F. M.: Simulated lower stratospheric trends between 1970 and 2005: Identifying the role of climate and composition changes, J. Geophys. Res., 113, D12301, doi:10.1029/2007jd009277, 2008.

Lamarque, J.-F., Bond, T. C., Eyring, V., Granier, C., Heil, A., Klimont, Z., Lee, D., Liousse, C., Mieville, A., Owen, B., Schultz, M. G., Shindell, D., Smith, S. J., Stehfest, E., Van Aardenne, J., Cooper, O. R., Kainuma, M., Mahowald, N., McConnell, J. R., Naik, V., Riahi, K., and van Vuuren, D. P.: Historical (1850-2000) gridded anthropogenic and biomass burning emissions of reactive gases and aerosols: methodology and application, Atmos. Chem. Phys., 10, 7017-7039, doi:10.5194/acp10-7017-2010, 2010a.

Lamarque, J.-F., Kyle, G. P., Meinshausen, M., Riahi, K., Smith, S. J., van Vuuren, D. P., Conley, A., and Vitt, F.: Global and regional evolution of short-lived radiatively-active gases and aerosols in the Representative Concentration Pathways, Climatic Change, in press, doi:10.1007/s10584-011-0155-0, 2010b.

Lee, A. M., Roscoe, H. K., and Oltmans, S.: Model and measurements show Antarctic ozone loss follows edge of polar night, Geophys. Res. Lett., 27, 3845-3848, doi:10.1029/2000gl011441, 2000.

Logan, J. A., Megretskaia, I. A., Miller, A. J., Tiao, G. C., Choi, D., Zhang, L., Stolarski, R. S., Labow, G. J., Hollandsworth, S. M., Bodeker, G. E., Claude, H., De Muer, D., Kerr, J. B., Tarasick, D. W., Oltmans, S. J., Johnson, B., Schmidlin, F., Staehelin, J., Viatte, P., and Uchino, O.: Trends in the vertical distribution of ozone: A comparison of two analyses of ozonesonde data, J. Geophys. Res., 104, 26373-26399, doi:10.1029/1999jd900300, 1999.

Marenco, A., Gouget, H., Nédélec, P., Pagés, J.-P., and Karcher, F.: Evidence of a long-term increase in tropospheric ozone from Pic du Midi data series: Consequences: Positive radiative forcing, J. Geophys. Res., 99, 16617-16632, doi:10.1029/94jd00021, 1994.

Meinshausen, M., Smith, S. J., Calvin, K., Daniel, J. S., Kainuma, M. L. T., Lamarque, J.-F., Matsumoto, K., Montzka, S., Raper, S., Riahi, K., Thomson, A., Velders, G. J. M., and van Vuuren, D. P.: The RCP Greenhouse Gas Concentrations and their Extensions from 1765 to 2300, Climatic Change, doi: doi:10.1007/s10584-011-0156-z, 2010.

Morgenstern, O., Braesicke, P., Hurwitz, M. M., O’Connor, F. M., Bushell, A. C., Johnson, C. E., and Pyle, J. A.: The World Avoided by the Montreal Protocol, Geophys. Res. Lett., 35, L16811, doi:10.1029/2008g1034590, 2008.

Morgenstern, O., Braesicke, P., O’Connor, F. M., Bushell, A. C., Johnson, C. E., Osprey, S. M., and Pyle, J. A.: Evaluation of the new UKCA climate-composition model - Part 1: The stratosphere, Geosci. Model Dev., 2, 43-57, doi:10.5194/gmd-2-432009, 2009.

Morgenstern, O., Giorgetta, M. A., Shibata, K., Eyring, V., Waugh, D. W., Shepherd, T. G., Akiyoshi, H., Austin, J., Baumgaertner, A. J. G., Bekki, S., Braesicke, P., Brühl, C., Chipperfield, M. P., Cugnet, D., Dameris, M., Dhomse, S., Frith, S. M., Garny, H., Gettelman, A., Hardiman, S. C., Hegglin, M. I., Jöckel, P., Kinnison, D. E., Lamarque, J. F., Mancini, E., Manzini, E., Marchand, M., Michou, M., Nakamura, T., Nielsen, J. E., Olivié, D., Pitari, G., Plummer, D. A., Rozanov, E., Scinocca, J. F., Smale, D., Teyssèdre, H., Toohey, M., Tian, W., and Yamashita, Y.: Review of the formulation of present-generation stratospheric chemistryclimate models and associated external forcings, J. Geophys. Res., 115, D00M02, doi:10.1029/2009jd013728, 2010.

Pawson, S., Stolarski, R. S., Douglass, A. R., Newman, P. A., Nielsen, J. E., Frith, S. M., and Gupta, M. L.: Goddard Earth Observing System chemistry-climate model simulations of stratospheric ozone-temperature coupling between 1950 and 2005, J. Geophys. Res., 113, D12103, doi:10.1029/2007jd009511, 2008.

Perlwitz, J., Pawson, S., Fogt, R. L., Nielsen, J. E., and Neff, W. D.: Impact of stratospheric ozone hole recovery on Antarctic climate, Geophys. Res. Lett., 35, L08714, doi:10.1029/2008g1033317, 2008.

Pitari, G., Mancini, E., Rizi, V., and Shindell, D. T.: Impact of Future Climate and Emission Changes on Stratospheric Aerosols and Ozone, J. Atmos. Sci., 59, 414-440, doi:10.1175/15200469(2002)059;0414:IOFCAE $\dot{c} 2.0 . C O ; 2,2002$.

Pope, V., Gallani, M., Rowntree, P., and Stratton, R.: The impact 
of new physical parametrizations in the Hadley Centre climate model: HadAM3, J. Climate, 16, 123-146, 2000.

Prather, M., Gauss, M., Berntsen, T., Isaksen, I., Sundet, J., Bey, I., Brasseur, G., Dentener, F., Derwent, R., Stevenson, D., Grenfell, L., Hauglustaine, D., Horowitz, L., Jacob, D., Mickley, L., Lawrence, M., von Kuhlmann, R., Muller, J.-F., Pitari, G., Rogers, H., Johnson, M., Pyle, J., Law, K., van Weele, M., and Wild, O.: Fresh air in the 21st century?, Geophys. Res. Lett., 30, 1100, doi:10.1029/2002gl016285, 2003.

Ramanathan, V. and Dickinson, R. E.: The Role of Stratospheric Ozone in the Zonal and Seasonal Radiative Energy Balance of the Earth-Troposphere System, J. Atmos. Sci., 36, 1084-1104, 1979.

Randel, W. J. and Wu, F.: A stratospheric ozone profile data set for 1979-2005: Variability, trends, and comparisons with column ozone data, J. Geophys. Res., 112, D06313, doi:10.1029/2006jd007339, 2007.

Rayner, N. A., Parker, D. E., Horton, E. B., Folland, C. K., Alexander, L. V., Rowell, D. P., Kent, E. C., and Kaplan, A.: Global analyses of sea surface temperature, sea ice, and night marine air temperature since the late nineteenth century, J. Geophys. Res., 108, 4407, doi:10.1029/2002jd002670, 2003.

Riahi, K., Grüblera, A., and Nakicenovica, N.: Scenarios of longterm socio-economic and environmental development under climate stabilization Technological Forecasting and Social Change, 74, 887-935, doi:10.1016/j.techfore.2006.05.026, 2007.

Rothman, L. S., Gamache, R. R., Tipping, R. H., Rinsland, C. P., Smith, M. A. H., Benner, D. C., Devi, V. M., Flaud, J. M., CamyPeyret, C., Perrin, A., Goldman, A., Massie, S. T., Brown, L. R., and Toth, R. A.: The HITRAN molecular database: Editions of 1991 and 1992, J. Quant. Spectrosc. Ra., 48, 469-507, doi:10.1016/0022-4073(92)90115-k, 1992.

Sanders, R. W., Solomon, S., Smith, J. P., Perliski, L., Miller, H. L., Mount, G. H., Keys, J. G., and Schmeltekopf, A. L.: Visible and Near-Ultraviolet Spectroscopy at McMurdo Station, Antarctica 9. Observations of OClO from April to October 1991, J. Geophys. Res., 98, 7219-7228, doi:10.1029/93jd00042, 1993.

Sanderson, M. G., Jones, C. D., Collins, W. J., Johnson, C. E., and Derwent, R. G.: Effect of Climate Change on Isoprene Emissions and Surface Ozone Levels, Geophys. Res. Lett., 30, 1936, doi:10.1029/2003g1017642, 2003.

Schraner, M., Rozanov, E., Schnadt Poberaj, C., Kenzelmann, P., Fischer, A. M., Zubov, V., Luo, B. P., Hoyle, C. R., Egorova, T., Fueglistaler, S., Brnnimann, S., Schmutz, W., and Peter, T.: Technical Note: Chemistry-climate model SOCOL: version 2.0 with improved transport and chemistry/microphysics schemes, Atmos. Chem. Phys., 8, 5957-5974, doi:10.5194/acp-8-59572008, 2008.

Scinocca, J. F., McFarlane, N. A., Lazare, M., Li, J., and Plummer, D.: Technical Note: The CCCma third generation AGCM and its extension into the middle atmosphere, Atmos. Chem. Phys., 8, 7055-7074, doi:10.5194/acp-8-7055-2008, 2008.

Shepherd, T. G.: Dynamics, stratospheric ozone, and climate change, Atmos.-Ocean, 46, 117-138, 2008.

Shibata, K. and Deushi, M.: Simulation of the stratospheric circulation and ozone during the recent past (1980-2004) with the MRI chemistry-climate model, Institute for Environmental Studies, Japan, 154 pp., 2008a.

Shibata, K. and Deushi, M.: Long-term variations and trends in the simulation of the middle atmosphere $1980-2004$ by the chemistry-climate model of the Meteorological Research Institute, Ann. Geophys., 26, 1299-1326, doi:10.5194/angeo-261299-2008, 2008b.

Shindell, D. T., Faluvegi, G., Unger, N., Aguilar, E., Schmidt, G. A., Koch, D. M., Bauer, S. E., and Miller, R. L.: Simulations of preindustrial, present-day, and 2100 conditions in the NASA GISS composition and climate model G-PUCCINI, Atmos. Chem. Phys., 6, 4427-4459, doi:10.5194/acp-6-4427-2006, 2006.

Solomon, S., Portmann, R. W., Sasaki, T., Hofmann, D. J., and Thompson, D. W. J.: Four decades of ozonesonde measurements over Antarctica, J. Geophys. Res., 110, D21311, doi:10.1029/2005jd005917, 2005.

Son, S.-W., Polvani, L. M., Waugh, D. W., Akiyoshi, H., Garcia, R., Kinnison, D., Pawson, S., Rozanov, E., Shepherd, T. G., and Shibata, K.: The Impact of Stratospheric Ozone Recovery on the Southern Hemisphere Westerly Jet, Science, 320, 1486-1489, doi:10.1126/science.1155939, 2008.

Son, S. W., Gerber, E. P., Perlwitz, J., Polvani, L. M., Gillett, N. P., Seo, K. H., Eyring, V., Shepherd, T. G., Waugh, D., Akiyoshi, H., Austin, J., Baumgaertner, A., Bekki, S., Braesicke, P., Brühl, C., Butchart, N., Chipperfield, M. P., Cugnet, D., Dameris, M., Dhomse, S., Frith, S., Garny, H., Garcia, R., Hardiman, S. C., Jöckel, P., Lamarque, J. F., Mancini, E., Marchand, M., Michou, M., Nakamura, T., Morgenstern, O., Pitari, G., Plummer, D. A., Pyle, J., Rozanov, E., Scinocca, J. F., Shibata, K., Smale, D., Teyssèdre, H., Tian, W., and Yamashita, Y.: Impact of stratospheric ozone on Southern Hemisphere circulation change: A multimodel assessment, J. Geophys. Res., 115, D00M07, doi:10.1029/2010jd014271, 2010.

SPARC CCMVal, SPARC Report on the Evaluation of ChemistryClimate Models, edited by: Eyring, V., Shepherd, T. G., and Waugh, D. W., SPARC Report No. 5, WCRP-132, WMO/TDNo. 1526, available at: http://www.atmosp.physics.utoronto.ca/ SPARC, 2010.

Stevenson, D. S., Johnson, C. E., Collins, W. J., Derwent, R. G., Shine, K. P., and Edwards, J. M.: Evolution of tropospheric ozone radiative forcing, Geophys. Res. Lett., 25, 3819-3822, doi:10.1029/1998g1900037, 1998.

Stevenson, D. S., Johnson, C. E., Collins, W. J., Derwent, R. G., and Edwards, J. M.: Future estimates of tropospheric ozone radiative forcing and methane turnover - impact of climate change, Geophys. Res. Lett., 27, 2073-2076, doi:10.1029/1999g1010887, 2000.

Stevenson, D. S., Dentener, F. J., Schultz, M. G., Ellingsen, K., van Noije, T. P. C., Wild, O., Zeng, G., Amann, M., Atherton, C. S., Bell, N., Bergmann, D. J., Bey, I., Butler, T., Cofala, J., Collins, W. J., Derwent, R. G., Doherty, R. M., Drevet, J., Eskes, H. J., Fiore, A. M., Gauss, M., Hauglustaine, D. A., Horowitz, L. W., Isaksen, I. S. A., Krol, M. C., Lamarque, J. F., Lawrence, M. G., Montanaro, V., Müller, J. F., Pitari, G., Prather, M. J., Pyle, J. A., Rast, S., Rodriguez, J. M., Sanderson, M. G., Savage, N. H., Shindell, D. T., Strahan, S. E., Sudo, K., and Szopa, S.: Multimodel ensemble simulations of present-day and near-future tropospheric ozone, J. Geophys. Res., 111, D08301, doi:10.1029/2005jd006338, 2006.

Stolarski, R. S. and Frith, S. M.: Search for evidence of trend slowdown in the long-term TOMS/SBUV total ozone data record: the 
importance of instrument drift uncertainty, Atmos. Chem. Phys., 6, 4057-4065, doi:10.5194/acp-6-4057-2006, 2006.

Taylor, K. E., Stouffer, R. J., and Meehl, G. A.: A Summary of the CMIP5 Experiment Design, available at: http://cmip.llnl.gov/ cmip5/docs/Taylor_CMIP5_design.pdf, 2009.

Teyssèdre, H., Michou, M., Clark, H. L., Josse, B., Karcher, F., Olivié, D., Peuch, V.-H., Saint-Martin, D., Cariolle, D., Attié, J.-L., Nédélec, P., Ricaud, P., Thouret, V., van der A, R. J., VolzThomas, A., and Chéroux, F.: A new tropospheric and stratospheric Chemistry and Transport Model MOCAGE-Climat for multi-year studies: evaluation of the present-day climatology and sensitivity to surface processes, Atmos. Chem. Phys., 7, 58155860, doi:10.5194/acp-7-5815-2007, 2007.

Thompson, D. W. J. and Solomon, S.: Interpretation of Recent Southern Hemisphere Climate Change, Science, 296, 895-899, doi:10.1126/science.1069270, 2002.

Thompson, D. W. J. and Solomon, S.: Recent Stratospheric Climate Trends as Evidenced in Radiosonde Data: Global Structure and Tropospheric Linkages, J. Climate, 18, 4785-4795, doi:10.1175/JCLI3585.1, 2005.

Thompson, D. W. J., Baldwin, M. P., and Solomon, S.: Stratosphere-Troposphere Coupling in the Southern Hemisphere, J. Atmos. Sci., 62, 708-715, doi:10.1175/JAS-3321.1, 2005.

Tian, W. and Chipperfield, M. P.: A new coupled chemistry-climate model for the stratosphere: The importance of coupling for future $\mathrm{O}_{3}$-climate predictions, Q. J. Roy. Meteorol. Soc., 131, 281-303, doi:10.1256/qj.04.05, 2005.
Tian, W., Chipperfield, M. P., Gray, L. J., and Zawodny, J. M.: Quasi-biennial oscillation and tracer distributions in a coupled chemistry-climate model, J. Geophys. Res., 111, D20301, doi:10.1029/2005jd006871, 2006.

van Vuuren, D., den Elzen, M., Lucas, P., Eickhout, B., Strengers, B., van Ruijven, B., Wonink, S., and van Houdt, R.: Stabilizing greenhouse gas concentrations at low levels: an assessment of reduction strategies and costs, Climatic Change, 81, 119-159, doi:10.1007/s10584-006-9172-9, 2007.

van Vuuren, D., Edmonds, J., Smith, S., Calvin, K., Karas, J., Kainuma, M., Nakicenovic, N., Riahi, K., van Ruijven, B., Swart, R., and Thomson, A.: What do near-term observations tell us about long-term developments in greenhouse gas emissions?, Climatic Change, 103, 635-642, doi:10.1007/s10584-010-99404, 2010.

World Meteorological Organization (WMO): United Nations Environment Programme (UNEP), Scientific Assessment of Ozone Depletion: 2006, World Meteorological Organization, Global Ozone Research and Monitoring Project, Report No. 50, Geneva, Switzerland, 2007.

Ziemke, J. R., Chandra, S., Labow, G. J., Bhartia, P. K., Froidevaux, L., and Witte, J. C.: A global climatology of tropospheric and stratospheric ozone derived from Aura OMI and MLS measurements, Atmos. Chem. Phys., 11, 9237-9251, doi:10.5194/acp11-9237-2011, 2011. 